\title{
Long-Term Effects of Targeted Killings by Unmanned Aerial Vehicles
}

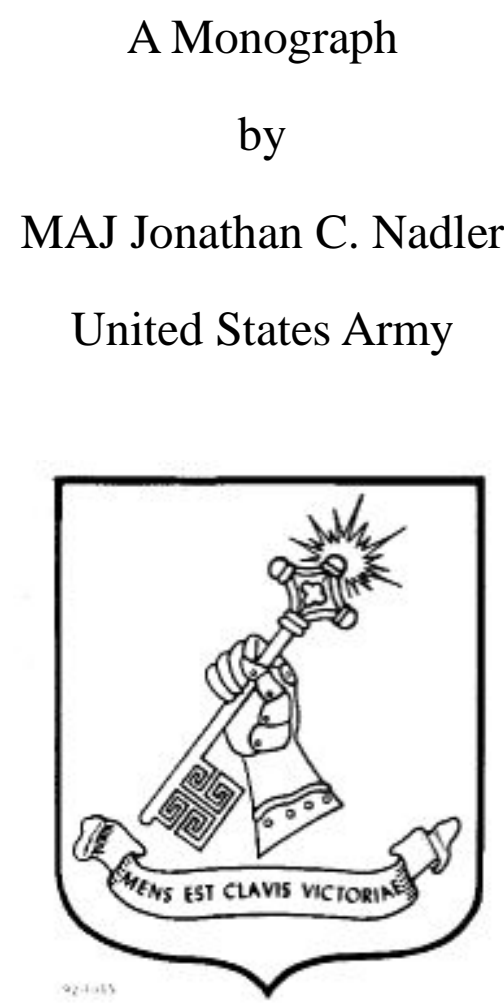

School of Advanced Military Studies

United States Army Command and General Staff College

Fort Leavenworth, Kansas

AY 2015-001 


\section{REPORT DOCUMENTATION PAGE}

Public reporting burden for this collection of information is estimated to average 1 hour per response, including the time for reviewing instructions, searching existing data sources, gathering and maintaining the data needed, and completing and reviewing this collection of information. Send comments regarding this burden estimate or any other aspect of this collection of information, including suggestions for reducing this burden to Department of Defense, Washington Headquarters Services, Directorate for Information Operations and Reports (0704-0188), 1215 Jefferson Davis Highway, Suite 1204, Arlington, VA 22202-4302. Respondents should be aware that notwithstanding any other provision of law, no person shall be subject to any penalty for failing to comply with a collection of information if it does not display a currently valid OMB control number. PLEASE DO NOT RETURN YOUR FORM TO THE ABOVE ADDRESS

1. REPORT DATE (DD-MM-YYYY)

03-04-2015

2. REPORT TYPE

3. DATES COVERED (From - To)

\section{TITLE AND SUBTITLE}

Monograph

\section{JUN 2014 - MAY 2015}

Long-Term Effects of Targeted Killings by Unmanned Aerial Vehicles

5a. CONTRACT NUMBER

5b. GRANT NUMBER

5c. PROGRAM ELEMENT NUMBER

6. AUTHOR(S)

MAJ Jonathan. C. Nadler 5d. PROJECT NUMBER

5e. TASK NUMBER

5f. WORK UNIT NUMBER

8. PERFORMING ORG REPORT NUMBER

10. SPONSOR/MONITOR'S ACRONYM(S)

11. SPONSOR/MONITOR'S REPORT NUMBER(S)

\section{DISTRIBUTION / AVAILABILITY STATEMENT}

Approved for Public Release; Distribution is Unlimited 
14. ABSTRACT

The struggle against Islamic extremism, which manifested in two long-term wars within Afghanistan and Iraq, simultaneously incited growth of an Unmanned Aerial Vehicle (UAV) industry dominated by the United States. Initially developed as reconnaissance and surveillance assets, UAVs quickly developed armed capabilities exploiting their stand-off reach and long-loiter times, and became preferred tools for targeted killings.

This study contributes to the growing discussion regarding the employment of weaponized UAVs, specifically when executing targeted killings outside designated combat zones. As the dominant proprietor of UAVs, the United States inadvertently established precedence for their employment resulting in significant, future political and military ramifications. The primary question within the study is, what are the long-term implications of the US policy on targeted killing of individuals, identified as threats to national security, by UAVs outside a theater of operations or within sovereign nations with which it is not at war?

This study proposes the way in which the United States currently employs UAVs in targeted killings is inadequately addressed in international law and difficult to justify on moral grounds. More importantly, US employment of UAVs risks establishing negative international precedents on killing outside a theater of operations as other nations develop UAV programs. To evaluate the contemporary practice of UAV targeted killings and reveal long-term effects, the study reviews Just War Theory and International Humanitarian Law / Law of Armed Conflict. Juxtaposed against these moral and legal frameworks, the study summarizes US legal justifications vindicating targeted killings by UAVs and presents the opposing legal arguments against the practice posited by the international community. To highlight the dangers of an emerging military precedence and public aversion to a weapons technology considered against the norms of war, this monograph uses case-study methodology to examine unrestricted submarine warfare during the interwar period, and post-World War II nuclear nonproliferation. Analysis of each case against the contemporary practice of UAV targeted killing reveals historical efforts to control a weapons technology, and exposes strengths and weaknesses applicable to future UAV employment control and nonproliferation efforts.

This study suggests that targeted killings by UAVs are not supported under Just War Theory; remain a contentious legal issue under international law; and result in a dangerous precedent for future conflicts. The greater long-term effect being establishment of a belief that, while evoking the right of self-defense and regardless of the weapons technology employed, states may disregard the norms of international law to initiate a preemptive attack. If the United States, as the current leader in UAV technologies, fails to shape efforts inhibiting acceptance of this precedent within the international norms of war, it risks losing a position of advantage and courts calamity in the future.

\section{SUBJECT TERMS}

Unmanned Aerial Vehicles; UAV; Targeted Killings; Just War Theory; International Humanitarian Law; IHL; Law of Armed Conflict; LOAC; unrestricted submarine warfare; nonproliferation; precedence

\begin{tabular}{|c|c|c|l|l|l|}
\hline \multicolumn{2}{|l|}{ 16. SECURITY CLASSIFICATION OF: } & $\begin{array}{l}17 . \\
\text { LIMITATION } \\
\text { OF ABSTRACT }\end{array}$ & $\begin{array}{l}\text { 18. NUMBER } \\
\text { OF PAGES }\end{array}$ & $\begin{array}{l}\text { 19a. NAME OF RESPONSIBLE PERSON } \\
\text { MAJ Jonathan C. Nadler }\end{array}$ \\
\cline { 1 - 2 } $\begin{array}{c}\text { a. REPORT } \\
\text { (U) ABSTRACT }\end{array}$ & $\begin{array}{c}\text { c. THIS PAGE } \\
\text { (U) }\end{array}$ & (U) & (U) & 49 & 19b. PHONE NUMBER (include area code) \\
\hline
\end{tabular}




\section{Monograph Approval Page}

Name of Candidate: MAJ Jonathan C. Nadler

Monograph Title: $\quad$ Long-Term Effects of Targeted Killings by Unmanned Aerial Vehicles

Approved by:

Eric R. Price, Professor

Monograph Director

Eric R. Price, Professor

(n)

, Seminar Leader

Robert J. Hallett, LtCol, USMC

$\stackrel{\text { Henry A. Arnold III, COL, IN }}{ }$ Director, School of Advanced Military Studies

Accepted this $3^{\text {rd }}$ day of April 2015 by:

Robert F. Baumann, Ph.D.

, Director, Graduate Degree Programs

The opinions and conclusions expressed herein are those of the student author, and do not necessarily represent the views of the U.S. Army Command and General Staff College or any other government agency. (References to this study should include the foregoing statement.) 


\begin{abstract}
Long-Term Effects of Targeted Killings by Unmanned Aerial Vehicles, by MAJ Jonathan C. Nadler, United States Army, 49 pages.

The struggle against Islamic extremism, which manifested in two long-term wars within Afghanistan and Iraq, simultaneously incited growth of an Unmanned Aerial Vehicle (UAV) industry dominated by the United States. Initially developed as reconnaissance and surveillance assets, UAVs quickly developed armed capabilities exploiting their stand-off reach and longloiter times, and became preferred tools for targeted killings.

This study contributes to the growing discussion regarding the employment of weaponized UAVs, specifically when executing targeted killings outside designated combat zones. As the dominant proprietor of UAVs, the United States inadvertently established precedence for their employment resulting in significant, future political and military ramifications. The primary question within the study is, what are the long-term implications of the US policy on targeted killing of individuals, identified as threats to national security, by UAVs outside a theater of operations or within sovereign nations with which it is not at war?

This study proposes the way in which the United States currently employs UAVs in targeted killings is inadequately addressed in international law and difficult to justify on moral grounds. More importantly, US employment of UAVs risks establishing negative international precedents on killing outside a theater of operations as other nations develop UAV programs. To evaluate the contemporary practice of UAV targeted killings and reveal long-term effects, the study reviews Just War Theory and International Humanitarian Law / Law of Armed Conflict. Juxtaposed against these moral and legal frameworks, the study summarizes US legal justifications vindicating targeted killings by UAVs and presents the opposing legal arguments against the practice posited by the international community. To highlight the dangers of an emerging military precedence and public aversion to a weapons technology considered against the norms of war, this monograph uses case-study methodology to examine unrestricted submarine warfare during the interwar period, and post-World War II nuclear nonproliferation. Analysis of each case against the contemporary practice of UAV targeted killing reveals historical efforts to control a weapons technology, and exposes strengths and weaknesses applicable to future UAV employment control and nonproliferation efforts.
\end{abstract}

This study suggests that targeted killings by UAVs are not supported under Just War Theory; remain a contentious legal issue under international law; and result in a dangerous precedent for future conflicts. The greater long-term effect being establishment of a belief that, while evoking the right of self-defense and regardless of the weapons technology employed, states may disregard the norms of international law to initiate a preemptive attack. If the United States, as the current leader in UAV technologies, fails to shape efforts inhibiting acceptance of this precedent within the international norms of war, it risks losing a position of advantage and courts calamity in the future. 


\section{Contents}

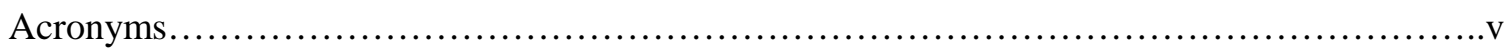

Introduction............................................................................

Just War Theory: Its Applicability to UAV Targeted Killings...............................6

International Humanitarian Law \& the Law of Armed Conflict: Their Applicability to UAV

Targeted Killings..................................................................11

The United States Interpretation of International Law..................................17

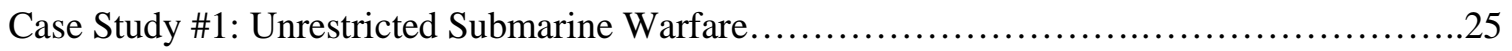

Case Study \#2: Nuclear Non-Proliferation............................................ 32

The Dangers of Current Policy and Controls Regarding UAVs...............................37

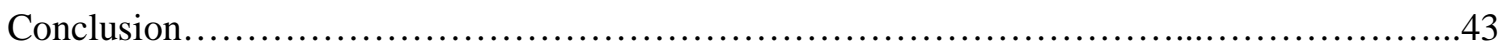

Recommendations................................................................46

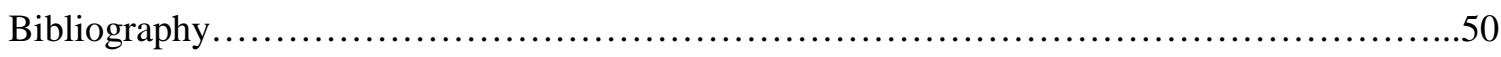




\section{Acronyms}

$\begin{array}{ll}\text { AUMF } & \text { Authorization for Use of Military Force } \\ \text { CCW } & \text { Convention on Certain Conventional Weapons } \\ \text { IAEA } & \text { International Atomic Energy Association } \\ \text { ICCPR } & \text { International Covenant on Civil and Political Rights } \\ \text { IHL } & \text { International Humanitarian Law } \\ \text { LOAC } & \text { Law of Armed Conflict } \\ \text { MTCR } & \text { Missile Technology Control Regime } \\ \text { POW } & \text { Prisoner of War } \\ \text { UAV } & \text { Unmanned Aerial Vehicle } \\ \text { WMD } & \text { Weapons of Mass Destruction }\end{array}$




\section{Introduction}

Very frankly, [air strikes by unmanned aerial vehicles are] the only game in town in terms of confronting or trying to disrupt the al Qaeda leadership.

—Leon Panetta, (former) Director, Central Intelligence Agency ${ }^{1}$

During a speech in 2009 given to the Pacific Council on International Policy, former Director Leon Panetta lauded successful air strikes by unmanned aerial vehicles (UAV) to target terrorist leadership within Pakistan. Also referred to as targeted killings, air strikes by UAVs are deemed "very effective" due to their precision in identifying and neutralizing even a single individual with few or no collateral civilian casualties. ${ }^{2}$ Yet the role of the armed UAV and its application against targets outside a designated combat zone did not occur without controversy.

The struggle against Islamic extremism—resulting from the attacks of 9/11 and manifesting in two long-term wars within Afghanistan and Iraq—simultaneously incited growth of a UAV industry dominated by the United States. Previously envisaged as primarily reconnaissance and surveillance assets, UAVs quickly developed armed capabilities exploiting their stand-off reach and long-loiter times over target areas. ${ }^{3}$ The first targeted killing occurred in Afghanistan in October of 2001, eliminating al Qaeda’s military chief, Muhammed Atef. ${ }^{4}$ Less than a year later, another targeted killing— executed in Yemen—-killed Qaed Salim Sinan al-

\footnotetext{
${ }^{1}$ Pam Benson, “U.S. Airstrikes in Pakistan Called 'Very Effective',” CNNPolitics.com, last modified May 8, 2009, accessed September 23, 2014, http://www.cnn.com/2009/POLITICS/05/18/cia.pakistan.airstrikes/.

${ }^{2}$ Ibid.

${ }^{3}$ Peter Bergen and Katherine Tiedemann, "Washington's Phantom War: The Effects of the U.S. Drone Program in Pakistan,” Foreign Affairs 90, no. 4 (2011), accessed March 8, 2015, http://www.foreignaffairs.com/articles/67939/peter-bergen-and-katherinetiedemann/washingtons-phantom-war.

${ }^{4}$ Daniel Byman, “Do Targeted Killings Work?” Foreign Affairs 85, no. 2 (2006), accessed March 8, 2015, http://www.foreignaffairs.com/articles/61513/daniel-byman/do-targetedkillings-work.
} 
Harethi, the architect of the U.S.S. Cole bombing in $2000 .{ }^{5}$ With this precedence established, targeted killing of individuals deemed a threat to the United States, whether inside or outside a designated combat zone, became accepted policy as part of the struggle against Islamic extremism.

Expansion of UAV strikes following these initial successes began in 2004 with the killing of Nek Muhammed, a Taliban commander in Pakistan, who vowed jihad against the United States. ${ }^{6}$ As both wars continued, the inherent difficulties in fighting an insurgency and the increasing reluctance of the American public towards casualties from both sides encouraged greater employment of UAV strikes. Once the Obama administration assumed office in 2008, many viewed the strikes as sterile instruments for precise operations against terrorists and UAV targeted killings outside combat zones increased-350 out of 361 strikes in Pakistan occurred between 2008 and 2014. ${ }^{7}$ Consequently, the United States continues to demonstrate with impunity the utility of armed UAVs to affect military targets, and the world has noticed.

Through 2005, the United States retained dominance in UAV technology and capabilities, and seemed unconcerned about establishing precedence for their use against belligerents. However, since 2005 the number of countries possessing UAVs increased from 40 to more than 75 with many advancing technologically towards more sophisticated or armed UAVs. ${ }^{8}$ According to Kenneth Anderson, a professor of law at American University, "this is the direction

${ }^{5}$ Byman, “Do Targeted Killings Work?”

${ }^{6}$ Brian Glyn Williams, “The CIA’s Covert Predator Drone War in Pakistan, 2004-2010: The History of an Assassination Campaign,” Studies in Conflict \& Terrorism 33 (2010): 871.

${ }^{7}$ Bill Roggio, “Charting the Data for US Airstrikes in Pakistan, 2004-2014,” The Long War Journal, last modified November 11, 2014, accessed September 23, 2014, http://www.longwarjournal.org/pakistan-strikes.php.

${ }^{8}$ US Government Accountability Office, Nonproliferation: Agencies Could Improve Information Sharing and End-Use Monitoring on Unmanned Aerial Vehicle Exports, by Thomas Melito, July 2012, 9. 
all aviation is going...everybody will wind up using this technology because it's going to become the standard for many, many applications of what are now manned aircraft." ${ }^{9}$ Militaries around the world witnessed the effectiveness of UAVs employed by the United States as an alternative to ground forces or conventional air strikes, and seek to replicate this relatively cheap weapons platform. The practice of targeted killing in remote locations via UAV, once solely a capability of the United States, is quickly becoming a reality for other nations.

This study contributes to the growing discussion regarding the employment of weaponized UAVs, specifically when executing targeted killings outside designated combat zones. As the dominant proprietor of UAVs over the past fourteen years, the United States inadvertently established precedence- — “an act or statement that serves or is intended to serve as an example, reason, or justification for a later one”-for their employment resulting in significant, future political and military ramifications. ${ }^{10}$ The primary question within the study is, what are the long-term implications of the US policy on targeted killing of individuals, identified as threats to national security, by UAVs outside a theater of operations or within sovereign nations with which it is not at war?

This study proposes that the way in which the United States currently employs UAVs in targeted killings, apart from combat operations, is inadequately addressed in international law and can be difficult to justify on moral grounds. More importantly, it risks establishing negative international precedence on killing outside a theater of operations as other nations develop UAV programs. To refute or support this hypothesis, this study examines the contemporary practice of

\footnotetext{
${ }^{9}$ William Wan and Peter Finn, “Global Race on to Match U.S. Drone Capabilities,” Washington Post, July 4, 2011, accessed August 15, 2014, http://www.washingtonpost.com/world/national-security/global-race-on-to-match-us-dronecapabilities/2011/06/30/gHQACWdmxH_story.html.

${ }^{10}$ Elizabeth Kier and Jonathan Mercer, "Setting Precedents in Anarchy: Military Intervention and Weapons of Mass Destruction,” International Security 20, no. 4 (Spring 1996): 77-106, accessed November 26, 2014, http://www.jstor.org/stable/2539043, 79.
} 
UAV targeted killings to reveal long-terms effects of such policy as countries develop UAV programs to emulate US military success. The study begins with a review of Just War Theory and the International Humanitarian Law (IHL) / Law of Armed Conflict (LOAC) to frame targeted killings in both moral and legal arguments, respectively. Next, the study summarizes the legal justifications presented by the United States, in its view vindicating targeted killings by UAVs, while also presenting the opposing legal arguments as posited by the international community. This comparison demonstrates the differing interpretations of established international law when applied to this relatively new method of warfare and the difficulties in resolving a contentious practice within the perceived norms of war.

To highlight the dangers of an emerging military precedence, this monograph uses a casestudy methodology to examine unrestricted submarine warfare during the interwar period, and post-World War II nuclear nonproliferation. The World War I employment of German submarines, that indiscriminately targeted merchantmen traversing the Atlantic, met with fierce criticism from the Allies yet was interpreted as necessary for survival by the German people. Analysis of unrestricted submarine warfare exemplifies a response to an emerging precedence through implementation of employment controls.

The development of nuclear weapons in the mid-twentieth century fueled an arms race between the United States and the Union of Soviet Socialist Republics (USSR, Soviet Union), both of whom viewed the possession and possible employment of the weapons an interest for national survival. The public reaction to nuclear weapons was more dramatic than to unrestricted submarine warfare because the United States and the Soviet Union embarked on a war of brinkmanship from first-strike through mutual-destruction and mutual deterrence policies. Analysis of nuclear nonproliferation reveals examples of attempts to control the spread of a new technology.

For the sake of specificity, this study uses employment control when referencing measures to constrain the use of a weapons system, rather than the broader term of arms control 
since the latter includes additional aspects of weapons controls not contained within the following analysis. Nonproliferation references measures taken to prevent the spread of weapons or associated technologies. Both case studies exemplify how employment of new technologies often run counter to the societal norm of accepted behavior in warfare; the almost certain emulation by states seeking to obtain parity in a technology and its benefits on the battlefield; and the positive or negative results from either an employment control or nonproliferation regime, respectively.

Relating to the contemporary dilemma of UAV targeted killings, which evoke domestic and international ire, submarines and nuclear weapons also met with increasing criticism and aversion from the international community. Deconstruction of individual cases and comparative analysis to UAV targeted killings reveals the strengths and weaknesses of each historical regime in controlling the employment and proliferation of new military technologies. Analysis of unrestricted submarine warfare during the interwar period provides insights into the development of policy regarding the possession and future employment of new weapons systems, while analysis of nuclear nonproliferation provides similar insights regarding agreements on regulation of new technologies to keep them from falling into the wrong hands. This enables the reconstruction of strengths from each case into a recommended future policy regarding UAV employment control and nonproliferation, while allowing the United States to retain a position of advantage.

This study suggests that targeted killings by UAVs are not supported under Just War Theory; remain a contentious legal issue under international law as interpreted by individual states; and result in establishing a dangerous precedence for future conflicts. Far beyond the immediate ramifications of escalating UAV employment within or outside a conflict, the greater long-term effect is the establishment of a belief that, while evoking the right of self-defense and regardless of the weapons technology employed, states may disregard the norms of international law — the status of conflict, the status of an individual target, location of that target, and the 
immediacy of a threat. In essence, legitimating preemptive attacks based on subjective interpretation of the immanency of a threat without respect to international law.

To mitigate these second and third-order effects resulting from the precedence established by UAV targeted killings, this study recommends the US-led creation of an international treaty regulating UAV employment and proliferation. The voluntary treaty would provide oversight through an international, organizational body that could regulate the use of UAVs during peacetime and conflict, promote the development of UAV technology for peaceful purposes, and prevent proliferation of dangerous UAV technologies. Consequently, the United States would retain its position of advantage by shaping current and future UAV policies while preventing promulgation of a negative precedence.

\section{Just War Theory: Its Applicability to UAV Targeted Killings}

War is innately violent, yet society continuously struggles to regulate when to go to war and how to wage war based on cultural values and norms. In many cases, societal values fueled aversion towards technologies that enabled greater capacity for killing or diminished vulnerability because they were considered immoral. For example, introduction of the English longbow impersonalized warfare by increasing the distance from those killed, while the pre-loaded crossbow increased lethality due to greater accuracy with less fatigue. In both cases, contemporary society, steeped in concepts of chivalry, was appalled. Civilians reacted with horror to the slaughtered masses of knights by archers at Agincourt, and the Pope produced an edict against crossbows having deemed them too murderous for "Christian warfare."11 UAVs, with their increased accuracy and stand-off capability, evoke similar feelings of impropriety or

\footnotetext{
${ }^{11}$ Ralph Peters, “A Revolution in Military Ethics?” Parameters (Summer 1996): 102-8, accessed December 18, 2014, http://strategicstudiesinstitute.army.mil/pubs/parameters/Articles/96summer/peters.htm; Edwin Tunis, Weapons: A Pictorial History (Baltimore: Johns Hopkins University Press, 1999), 62.
} 
immorality when framed against traditional, accepted warfare. Consequently, analysis of Just War Theory, its origins, and application towards UAV targeted killings is appropriate.

The current manifestation of Just War Theory_-jus ad bellum (right to war) and jus in bello (the law in waging war) - is the culmination of mankind's attempt to regulate warfare. ${ }^{12} \mathrm{~A}$ unity of thought that war should be controlled spawned Just War Theory, and individuals like Cicero, Thomas Aquinas, Francisco de Vitoria, and Hugo Grotius advanced religious or secular justifications for conflict that were adapted over time and codified in the twentieth century. More applicable towards inter-state warfare, Just War Theory is harder to apply to conflicts of the twenty-first century when non-state actors and unconventional warfare are the norm and require different approaches, like targeted killings, to eliminate threats.

In the first century B.C., Cicero provided the foundational basis of jus ad bellum with which modern society is familiar. Cicero stated, "no war can be undertaken by a just...state, unless for faith or self-defense,” and wars undertaken without provocation or without providing time for restitution of grievances were unjust. ${ }^{13}$ Saint Augustine expanded these foundational ideas based upon his experiences as a converted Christian and applied religious justifications for the use of force in conflict. In the Middle Ages, Saint Thomas Aquinas applied secular justifications towards jus ad bellum believing only human reason could distinguish between right or wrong moral choices making it, rather than religious texts, the sole determinant for just and unjust human laws. ${ }^{14}$

\footnotetext{
${ }^{12}$ Eric Patterson, Just War Thinking: Morality and Pragmatism in the Struggle against Contemporary Threats (Plymouth, UK: Lexington Books, 2007), 18.

${ }^{13}$ Marcus Tullius Cicero, “Book III,” in De Re Publica [Concerning the 'Republic' or 'Commonwealth'], trans. Francis Barham (Mohrsville, PA: Kings Academy, 2011), under "Fragments,” accessed January 22, 2015, http://www.kingsacademy.com/mhodges/08_ClassicsLibrary/hellenist-roman/cicero/de-re-publica/de-re-publica.htm.

${ }^{14}$ Paul Christopher, The Ethics of War and Peace: An Introduction to Legal and Moral Issues, $3^{\text {rd }}$ ed. (New Jersey: Person/Prentice Hall, 2004), 49.
} 
Aquinas believed that man desires to live in a society for the inherent benefits of protection and prosperity. These societies became states that existed to provide justice and order (the common good) with human laws enforcing the common good over individual liberties within the state. ${ }^{15}$ From this reasoning, Aquinas organized the original three conditions of jus ad bellum to independently or cumulatively justify war. The first condition, proper authority, states only the leader of a state may initiate a conflict. Individuals are prohibited from waging war privately due to their ability to appeal to societal authority for the redress of grievances. Consequently, the sovereign is responsible and endowed with the power to protect the society. ${ }^{16}$ The second condition, just cause, maintains the targeted state warrants redress for a previous fault against the aggressor state, i.e. to avenge a wrong-doing. ${ }^{17}$ Although synonymous with self-defense, Aquinas noted that just cause must be weighed against the concept of double-effect-acts having both good and bad effects are permissible so long as the good effect is intended. For example, an act of self-defense resulting in the death of another is justified so long as that death was not intended. ${ }^{18}$ The third condition, right intention, maintains an aggressor state must attempt the advancement of a good or an avoidance of evil. ${ }^{19}$ Aquinas additionally stressed the concept of proportionality (later adopted within Just War Theory), knowing that for a war to remain just, the harm inflicted during a conflict cannot exceed the harm initiating conflict. ${ }^{20}$ From these three conditions, Just War Theory expanded beyond simply justifying a war.

\footnotetext{
${ }^{15}$ Christopher, The Ethics of War and Peace, 50.

${ }^{16}$ Thomas Aquinas (Saint), The Summa Theologica, ed. and trans. Fathers of the English Dominican Province (Benziger Brothers Edition, 1947), accessed on September 21, 2014, http://dhspriory.org/thomas/summa/.

${ }^{17}$ Aquinas, The Summa Theologica; Christopher, The Ethics of War and Peace, 51.

${ }^{18}$ Christopher, The Ethics of War and Peace, 52.

${ }^{19}$ Aquinas, The Summa Theologica.

${ }^{20}$ Christopher, The Ethics of War and Peace, 52.
} 
Francisco de Vitoria, a Spanish philosopher in the fifteenth century, first promoted regulating actions during war-jus in bello-after witnessing Spanish actions in North America against Native Americans. He argued that war must not harm innocents, the peaceable population, or those not directly involved in the fighting. ${ }^{21}$ Regarding the killing of innocents he said,

Great attention...must be paid...to see that greater evils do not arise out of the war than the war would avert... In sum, it is never right to slay the guiltless, even as an indirect and unintended result, except when there is no other means of carrying on the operations of a just war. ${ }^{22}$

Vitoria expanded Aquinas' concept of double-effect; acknowledging the killing of innocents is acceptable only if there are no other means with which to wage war, exhaustion of all other options, and special status is granted to civilians to protect them from warfare. ${ }^{23}$ Thus, Vitoria introduced the initial conditions of proportionality and discrimination within jus in bello. ${ }^{24}$

Hugo Grotius, a seventeenth century Dutchman, strove to establish the objective of secular authority, i.e. international law, accepted by individual states on the basis of reason rather than religion. Like Aquinas, Grotius believed in the attraction of society—a community bonded by pacts — which promotes the welfare of individuals and binds them under law. ${ }^{25}$ Applying this idea to the macro-level of a global community, Grotius believed laws between nations regulating state conduct relied on consent of the states within an international society.

Just as the laws of each state have in view the advantage of that state, so by mutual consent it has become possible that certain laws should originate as between all states, or in a great many states; and it is apparent that the laws thus originating had in view the advantage, not of particular states, but of the great society of states. And this is what is

\footnotetext{
${ }^{21}$ Christopher, The Ethics of War and Peace, 52.

${ }^{22}$ Franciscus de Victoria, De Indis Et de Ivre Belli Relectiones (Being Parts Of) Relectiones Theologicae XII, in The Classics of International Law, ed. James Brown Scott and Ernest Nys, trans. John Pawley Bate (Washington: Carnegie Institution of Washington, 1917), 179, accessed January 17, 2015, http://babel.hathitrust.org/cgi/pt?id=mdp.39015039506772;view=1up;seq=11.

${ }^{23}$ Christopher, The Ethics of War and Peace, 56.

${ }^{24}$ Christopher, The Ethics of War and Peace, 56; Patterson, Just War Thinking, 2.

${ }^{25}$ Christopher, The Ethics of War and Peace, 66-98.
} 
called the law of nations... ${ }^{26}$

The idea of an international community, bound by international law, corresponded with Just War Theory. Grotius' The Law of War and Peace sought to minimize brutality in war by dictating criteria for evaluating the causes and necessities for war. ${ }^{27}$ Consequently, Grotius modified the just cause condition arguing it did not justify anticipatory attacks or attacks designed to maintain security, noting that "the possibility of being attacked confers the right to attack is abhorrent to every principle of equity. Human life exists under such conditions that complete security is never guaranteed to us." ${ }^{28}$ Grotius formally confirmed the condition of proportionality as well as adding the conditions of a reasonable chance of success, a public declaration of war, and last resort. ${ }^{29}$

By the twentieth century, the evolution of Just War Theory as ratified within the Geneva Conventions, United Nations Charter, and other international accords resulted in a set of criteria for jus ad bellum and jus in bello. Unlike Aquinas’ initial conditions, which could be met individually or cumulatively, the current trend requires a state meet most, if not all, conditions in order to justify a war. As a result, a state must provide a just cause, prove comparative justice (the injustice suffered by one state outweighs that of the other), initiate with legitimate authority, act

\footnotetext{
${ }^{26}$ Hugo Grotius, "Prolegomena," in The Law of War and Peace (1625), trans. Francis Kelsey (New York: Bobbs-Merrill, 1962), accessed January 17, 2015, http://lonang.com/library/reference/grotius-law-war-and-peace/gro-201/.

${ }^{27}$ Christopher, The Ethics of War and Peace, 66-98.

${ }^{28}$ Hugo Grotius, “Book II, Chapter 1,” in The Law of War and Peace (1625), trans. Francis Kelsey (New York: Bobbs-Merrill, 1962), under "XVII: A public war is not admitted to be defensive which has as its only purpose to weaken the power of a neighbor," accessed January 17, 2015, http://lonang.com/library/reference/grotius-law-war-and-peace/gro-201/.

${ }^{29}$ Christopher, The Ethics of War and Peace, 85. A reasonable chance of success required nations ensure a war had some chance of success without leading to suicidal confrontation; public declaration of war ensured the offending nation had the ability to redress a grievance and prevented privately waged wars between states by announcing the conflict to the populations within the conflict; and last resort ensured all other conditions were attempted for peaceful resolution prior to resorting to conflict.
} 
with right intention, have a high probability of success, demonstrate proportionality, and have war be a last resort after all other peaceful measures fail. ${ }^{30}$ States must also meet the moral standards for conduct within war by providing non-combatant immunity, effecting tactical proportionality, and ensuring soldiers act with right intentions. ${ }^{31}$

Since Just War Theory developed during periods of warfare between nation-states, it became a contemporary check-list for international recognition of a justified conflict. This application fails to account for the unconventional warfare of the twenty-first century or the complications of fighting entities outside the nation-state paradigm. Consequently, it is difficult to justify targeted killings within Just War Theory. Granted, targeted killings discriminate and provide for proportionality, but they fail to account for other conditions of Just War Theory. Primarily, Just War Theory applies only to inter-state warfare but the enduring conflicts that spawned targeted killings are not a part of this type of conflict-many individuals belong to extremist or terrorist organizations and targeted for this affiliation rather than nationality. Additionally, targeted individuals are rarely offered the opportunity (however unlikely) to redress grievances of the United States before an attack. Targeted killings are also precision operations intended to limit casualties, but if used in a preemptive nature they are unjust according to Grotius. Finally, targeted killings are now a first course of action to address the constraints of discrimination and proportionality, but this contradicts jus ad bellum's contemporary edict of war as a last resort. Consequently, the US policy of targeted killings by UAVs is not supported by this checklist application of Just War Theory.

\section{International Humanitarian Law (IHL) and the Law of Armed Conflict (LOAC): Their Applicability to UAV Targeted Killings}

Analyzing targeted killings via UAVs by moral standards is difficult due to the modern trend of treating Just War Theory as a collectively justifying check-list rather than independent

\footnotetext{
${ }^{30}$ Patterson, Just War Thinking, 82.

${ }^{31}$ Ibid, 91-98.
} 
conditions. Additionally, moral considerations and their interpretation, regardless of their foundations, may differ amongst nations making consensus and adherence virtually impossible. Understanding International Humanitarian Law (IHL) and the Law of Armed Conflict (LOAC) provides a more robust argument to support or refute the efficacy of targeted killings because these frameworks are treaty-based and bound by customary international law.

International Humanitarian Law (IHL) is composed of the four treaties of the Geneva Conventions of 1949, Additional Protocols I \& II of 1977, and Additional Protocol III of 2005, all of which establish rules once armed violence becomes armed conflict. ${ }^{32}$ At its core are the protection of civilians or the victims of conflict, civilian property, and limiting the weapons employed by belligerents. ${ }^{33}$

To stress significance, approximately a dozen common articles are reiterated verbatim throughout each of the four Geneva Conventions. Common Articles 2 and 3 are important because they determine protections provided to participants within specific types of conflict. An armed conflict involving two or more states is an Article 2 International Armed Conflict, and evokes all four 1949 Geneva Conventions as well as the additional protocols. ${ }^{34}$ An armed conflict occurring in the territory of a state but not between two states is an Article 3 Non-International

\footnotetext{
${ }^{32}$ International Committee of the Red Cross (ICRC), International Humanitarian Law and the Challenges of Contemporary Armed Conflicts (Geneva, Switzerland: $30^{\text {th }}$ International Conference of the Red Cross and Red Crescent, 2007): 1-5; Gary D. Solis, The Law of Armed Conflict: International Humanitarian Law in War (New York, NY: Cambridge University Press, 2010), 83-85.

${ }^{33}$ Solis, The Law of Armed Conflict, 83. The four Geneva Conventions are the Geneva Convention for the Amelioration of the Condition of the Wounded and Sick in Armed Forces in the Field (GC I), Geneva Convention for the Amelioration of the Condition of Wounded, Sick, and Shipwrecked Member of the Armed Forces at Sea (GC II), Geneva Convention Relative to the Treatment of Prisoners of War (GC III), and Geneva Convention Relative to the Protection of Civilian Persons in Time of War (GC IV). The three protocols address the protection of victims or civilians within an international or non-international conflict, as well as establishing adopted markings that identify protected persons.

${ }^{34}$ Solis, The Law of Armed Conflict, 150.
} 
(or Internal) Armed Conflict, and does not provide the protections of the four Geneva Conventions. As such, Article 3 conflicts require, at a minimum, individuals hors de combat (out of combat) be afforded basic humanitarian protections. ${ }^{35}$ As a whole, IHL is focused on the protection of non-combatants during on-going hostilities and provides the basis for the contemporary Law of Armed Conflict (LOAC).

The LOAC, like International Humanitarian Law, is based on treaties and international agreements regulating the conduct of belligerents. Unlike International Humanitarian Law, the LOAC primarily focuses on protection of non-combatants through restraint of combatants, rather than the rights of non-combatants. Key components under the LOAC are the status of a conflict, individuals' status within a conflict, the four principles of the LOAC, and the targeting process during a conflict.

As briefly described in IHL, the status of conflict determines the protection afforded to participants within the Geneva Conventions. There are only two types of conflict: Article 2 International Armed Conflicts and Article 3 Non-International Armed Conflicts. Designation of a conflict and application of the appropriate Geneva Convention protections involving non-state actors or armed opposition groups is difficult and based on a myriad of criteria. Primarily, if a group possesses a chain of command, is capable of planning attacks, and is capable of conducting sustained confrontation then they are involved in an Article 3 Non-International Conflict. Otherwise, it is simply a criminal organization within the Geneva construct violating national law.

The status of a conflict determines the status of individuals involved; the rights and protections of the fighters if captured, and the rules affecting their conduct during the conflict. In

\footnotetext{
${ }^{35}$ International Committee of the Red Cross, Treaties and States Parties to Such Treaties, "Convention (III) Relative to the Treatment of Prisoners of War, Geneva, 12 August 1949," accessed January 17, 2015, https://www.icrc.org/ihl/WebART/375-590006.
} 
Article 2 International Conflicts, there are combatants and non-combatants. ${ }^{36}$ As combatants under an Article 2 conflict, individuals are provided full protection under the Geneva Conventions and Protocols if captured and placed in a Prisoner of War (POW) status. In Article 3 conflicts, the delineation between combatants and non-combatants is more difficult. In many cases, the international community recognizes the armed force of a non-state entity as unlawful combatants - those persons engaging in a continuous combat function without authorization to take part in direct hostilities. ${ }^{37}$ As such, they are not afforded protections under the Geneva Conventions because they are not recognized as combatants with applicable POW rights. However, similar to a combatant an unlawful combatant, in a continuous combat status, is subject to targeting whenever positively identified. ${ }^{38}$ In sum, the individual status of persons on the battlefield determines their role and protections within the identified conflict.

36“Customary International Humanitarian Law (IHL): Rules by Chapter,” under Rules 3, 5, \& 6, International Committee of the Red Cross: Customary International Humanitarian Law (IHL), 2015, accessed January 30, 2015, https://www.icrc.org/customary-ihl/eng/docs/v1_cha. Customary International Humanitarian Law defines combatants within an Article 2 conflict as all members of the armed forces of a party to the conflict, except medical and religious personnel. During Article 3 conflicts, Geneva Conventions and Additional Protocol II refer to "armed forces" and "dissident armed forces and other organized armed groups," with state forces possibly being considered combatants for the sole purpose of distinction. Persons directly participating in an Article 3 conflict are sometimes labeled "combatants” but this term is only used to denote these individuals do not enjoy the same protection afforded to civilians (as defined as persons who are not members of the armed forces), and are not afforded the same rights as combatants under Article 2 conflicts. Consequently, persons or civilians are not protected against attack or considered non-combatants when they take a direct part in hostilities.

${ }^{37}$ International Review of the Red Cross, Interpretive Guidance on the Notion of Direct Participation in Hostilities under International Humanitarian Law (Geneva: International Committee of the Red Cross, 2009), 995; Solis, The Law of Armed Conflict, 207.

${ }^{38}$ International Review of the Red Cross, Interpretive Guidance on the Notion of Direct Participation in Hostilities under International Humanitarian Law, 1002; Solis, The Law of Armed Conflict, 208 \& 212. 
Four fundamental principles originating from Just War Theory underscore the LOAC: distinction, military necessity, unnecessary suffering, and proportionality. Although inherently applicable to Article 2 conflicts, these core tenets are relevant to all conflicts.

Distinction mandates the protection of civilians on the battlefield by requiring belligerents to differentiate between combatants and civilians. The concept of distinction is akin to the jus in bello concept of discrimination by emphasizing attacks only on identified combatants or military objectives, and requires combatants distinguish themselves and their equipment apart from civilians. As stated in Additional Protocol I, Article 48:

In order to ensure respect for and protection of the civilian population and civilian objects, the Parties to the conflict shall at all times distinguish between the civilian population and combatants and between civilian objects and military objectives and accordingly shall direct their operations only against military objectives. ${ }^{39}$

Although non-state actors or armed opposition groups routinely disregard the LOAC, the rule of distinction applies to any conflict, to include guerilla wars or insurgencies, and protects civilians until they participate directly in hostilities. All parties within a conflict are accountable for violations of this principle.

Military necessity means applying the amount of lethal force necessary to compel the end of hostilities. Collateral damage or civilian casualties are acceptable as long as the application of lethal force is directed at military targets and results in a military advantage. Military necessity is linked to the subsequent principles of unnecessary suffering and proportionality by attempting to gain a military advantage while limiting human suffering and destruction. ${ }^{40}$

39“"Protocol Additional to the Geneva Convention of 12 August 1949, and Relating to the Protection of Victims of International Armed Conflicts (Protocol I), 8 June 1977,” ICRC: Treaties and States Parties to Such Treaties, accessed January 17, 2015, https://www.icrc.org/ihl/4e473c7bc8854f2ec12563f60039c738/8a9e7e14c63c7f30c12563cd0051 dc5c?OpenDocument.

${ }^{40}$ Solis, The Law of Armed Conflict, 259. 
Unnecessary suffering entails the prohibition of certain weapons, projectiles, or methods of warfare that cause undue suffering on the target. Harkening back to the ideal of jus in bello, this principle intends to limit the suffering between combatants rather than directly referencing civilian suffering. Weapons or methods are not banned due to the degree of suffering inflicted but on comparison between suffering and the military advantage gained—a similar concept to proportionality. ${ }^{41}$ Proportionality is the final principle within LOAC and intended to limit the death and suffering of civilians. Originating from the proportionality described by Aquinas and Vitoria, the modern definition requires belligerents attacking a military target ensure any resulting civilian collateral damage is less than the military advantage gained. ${ }^{42}$

Examining the practicability of targeted killings by UAVs according to IHL and the LOAC is more straightforward than Just War Theory. For example, in 2001 the United States engaged in an Article 2 conflict against the Taliban due to the latter's recognition as the legitimate government constituting the state of Afghanistan. Once the Taliban were replaced by an internationally legitimated government, upon whose request the United States continued to operate within Afghanistan, the conflict converted into an Article 3 conflict. Consequently, the current state of conflict between the United States and Al Qaeda is an Article 3 conflict because it is between a state government (assisted by the United States) and an armed opposition group comprised of "enemy combatants” (which includes lawful and unlawful combatants) whether in Pakistan, Yemen, or Afghanistan. Although these groups or their militant arm may confront a state's forces outside the state's territory, it is remains an Article 3 conflict. Consequently, armed opposition groups lacking a chain-of-command and disciplinary hierarchy, within an Article 2 or 3 conflict, are unlawful combatants in a continuous combat function and are legitimate targets at

41“Rule 70. Weapons of a Nature to Cause Superfluous Injury or Unnecessary Suffering,” ICRC: Customary IHL, accessed January 22, 2015, https://www.icrc.org/customaryihl/eng/docs/v1_cha_chapter20_rule70\#Fn_66_23.

${ }^{42}$ Army Doctrine Publication (ADP) 1-0, The Army Profession (Washington, DC: Government Printing Office, 2013), 2-7. 
any time and in any location after correct identification. ${ }^{43}$ As described below, the United States' targeting process enables distinction between unlawful combatants and civilians, enables military necessity by targeting high-ranking individuals in an attempt to quickly end the conflict, and prevents unnecessary suffering while accounting for proportionality through precision strikes. Although the legal framework of the LOAC adds credibility and legitimacy to targeted killing strikes due to the agreements upon which IHL and LOAC are established, international interpretation of the laws differ and fuels dissention with US justification under the law regarding current practices. It is not surprising then, that the United States has continuously utilized a legal framework as its strongest argument supporting its targeted killing policy and refute claims that it violates international law.

\section{The United States Interpretation of International Law}

As targeted killings increased during the wars in Afghanistan and Iraq both inside and outside designated combat zones, the United States, under increasing scrutiny, continuously asserted such attacks were justified by the laws of war. In 2003, the UN Special Rapporteur levied a case against the United States citing UAV strikes in Yemen during a 2002 operation as “a clear case of extrajudicial killing." 44 The allegation argued the right to life and security of the individuals killed were protected under the Universal Declaration on Human Rights and the

${ }^{43}$ Solis, The Law of Armed Conflict, 212 \& 218-219; Mary Ellen O'Connell, International Law and the Use of Force (New York: Foundation Press, 2005), 531-32. William J. Haynes II, General Counsel of the Department of Defense wrote, "[President G.W. Bush] determined Al Qaida members are unlawful combatants...because they are members of a non-state actor terrorist group that does not receive the protections of the Third Geneva Convention....although the President's determination on this issue is final, [US] courts have concurred with his determination." For further discussion on combatant status reference George H. Aldrich, "The Taliban, Al Qaeda, and the Determination of Illegal Combatants," American Journal of International Law 96, no. 4 (October 2002): 891-98, accessed February 12, 2015, http://www.jstor.org/stable/3070684?seq=1\#page_scan_tab_contents.

${ }^{44}$ Jeffrey De Laurentis, Civil and Political Rights, Including the Questions of: Disappearances and Summary Executions, United Nations Economic and Social Council, Commission on Human Rights, $59^{\text {th }}$ sess., Agenda item 11(b) (Geneva, Switzerland, 2003), 3. 
International Covenant on Civil and Political Rights (ICCPR). The indictment acknowledged a nation's right to defend itself or its citizens from a non-state threat or actor, but viewed the operations in Yemen beyond this justification. In a letter to the United Nations Commission on Human Rights, the United States justified the killings through multiple legal precedents. Specifically, after the 9/11 attacks the United Nations recognized Al Qaeda as a "threat to international peace and security” and such an attack by an international terrorist organization is covered under Article 5 of the Washington Treaty which states, "an attack on one or more of the Allies of Europe or North America shall be considered an attack against them all.” Also, within US law former President Bush enacted Military Order Number 1 in November 2001, stating the scale of the 9/11 attacks constituted an armed conflict and allowed the use of US Armed Forces in response. Finally, and in direct response to the allegation, the United States argued IHL governs armed conflict and determines whether or not a person was arbitrarily deprived of life. Consequently, identified enemy combatants may be attacked unless they surrender or otherwise unable to continue fighting. Since Al Qaeda terrorists continue to plot attacks against the United States, they remain lawful targets regardless of location. ${ }^{45}$ Additionally, in 2002 Yemini President Ali Abdullah Saleh approved the use of US Predator drones within the country to target Al Qaeda operatives, while current President Abed Rabbo Mansour Hadi stated in 2012 that he personally approved every UAV strike. ${ }^{46}$ Consequently, all actions by the United States at the request of Yemeni presidents constituted an Article 3 conflict, which supports the US position

\footnotetext{
${ }^{45}$ De Laurentis, Civil and Political Rights, Including the Questions of: Disappearances and Summary Executions, 3.

${ }^{46}$ Drones Team, "Yemen: Reported US Covert Actions 2001-2011,” The Bureau of Investigative Journalism, March 29, 2012, accessed November 29, 2014, http://www.thebureauinvestigates.com/2012/03/29/yemen-reported-us-covert-actions-since2001/; Greg Miller, "Yemeni President Acknowledges Approving U.S. Drone,” Washington Post, September 29, 2012, accessed November 29, 2014, http://www.washingtonpost.com/world/national-security/yemeni-president-acknowledgesapproving-us-drone-strikes/2012/09/29/09bec2ae-0a56-11e2-afff-d6c7f20a83bf_story.html.
} 
that targeted individuals were not arbitrarily deprived of life. By this interpretation of the LOAC, the United States justified and continued using UAVs for targeted killings, but did not effectively silence critics of the US policy.

In 2010, President Barack Obama under whose administration targeted killings increased, reaffirmed the policy on legal grounds. ${ }^{47}$ Addressing concerns regarding the use of UAVs and armed force while fighting extremist organizations, President Obama stated, "the world must remember that it was not simply international institutions—-not just treaties and declarationsthat brought stability to a post-World War II world...[T]he instruments of war do have a role to play in preserving the peace.” 48

Supporting the Obama administration, Harold Hongju Koh, Legal Advisor within the US Department of State, spoke to an annual meeting of the American Society of International Law to address concerns by reinforcing the administration was "firmly committed to complying with all applicable law, including the laws of war, in all aspects of these ongoing conflicts." ${ }^{49}$ Koh’s address refuted objections to the policy of targeted killings by citing both national law and the international LOAC. Specifically, the United States’ targeting practices and lethal operations by UAVs remained consistent with the right of self-defense and the Authorization for Use of Military Force (AUMF)—a domestic law passed by Congress in 2001 authorizing all necessary types of force. Koh stated the LOAC further allows a nation to conduct cross-border attacks in self-defense within another sovereign state if that state is incapable or unwilling to confront a belligerent non-state entity involved in the conflict. ${ }^{50}$

${ }^{47}$ Bill Roggio, “Charting the Data for US Airstrikes in Pakistan, 2004-2014.”

${ }^{48}$ Harold Hongju Koh, “The Obama Administration and International Law” (lecture, Annual Meeting of the American Society of International Law, Washington, DC, March 25, 2010), 1, accessed on September 4, 2014, http://www.state.gov/s/l/releases/remarks/139119.htm.

${ }^{49}$ Ibid.

${ }^{50}$ Ibid. 
Referring to Just War Theory, Koh stated that US targeting procedures during UAV strikes were thoroughly reviewed and adjusted to ensure the protection of civilians under the LOAC. US targeting procedures distinguished between military targets and civilians; addressing proportionality by prohibiting attacks expected to have any combination of injury, death, or damage to civilian life or property excessive in relation to the concrete and direct military advantage of the attack. ${ }^{51}$

Koh further justified the United States’ policy on targeted killings by UAVs against four direct accusations: targeting enemy leaders violates the law of war, advanced weapon systems in lethal targeting violates LOAC, lethal force against individuals is a violation of due process and is equivalent to extrajudicial killing, and targeted killings violates US domestic law against assassinations. Regarding targeting enemy leaders, Koh emphasized targeted individuals were belligerents and lawful targets under international law. Koh reiterated that the LOAC does not prohibit technologically advanced weapon systems, such as UAVs, from executing targeting operations. Moreover, Koh adamantly stated America does not engage in extrajudicial killing or assassinations. States engaged in armed conflict or evoking the right of self-defense are not required to provide targets with due process prior to the employment of lethal force, and under domestic law targeting belligerent leaders utilizing lawful weapon systems does not equate to assassination. ${ }^{52}$

Over the next two years, legal objections to targeted killings by UAVs continued to arise. In 2011 John Brennan, White House chief counter-terrorism adviser, reinforced Koh’s justifications and further validated the Obama administration's view on the legality of targeted killings. During an address at Harvard Law School, Brennan reiterated the United States was in conflict with Al Qaeda and, as a result, had the inherent right of self-defense as defined under

\footnotetext{
${ }^{51}$ Koh, “The Obama Administration and International Law.”

${ }^{52}$ Ibid.
} 
international law. He further clarified that although the United States was not limited "[to only] 'hot' battlefields," this did not mean that "[the United States] can use military force whenever we want, wherever we want. International legal principles, including respect for a state’s sovereignty and the laws of war, impose important constraints on our ability to act unilaterally—and on the way in which we can use force-in foreign countries.”53 In 2012, Attorney General Eric Holder elaborated on the US commitment to other nations’ sovereignty, stating international law constrains US actions. Echoing Koh's legal argument, only when granted consent by a nation, or if that nation is unwilling or unable to mitigate a threat to the United States, will US force be used within a foreign country. ${ }^{54}$ Holder implied that determining the immanency of a threat, based on a "relevant window of opportunity to act, the possible harm...to civilians, and the likelihood of heading off future disastrous attacks,” factors heavily into these considerations. ${ }^{55}$ Since Al Qaeda can strike with little notice, does not act like a traditional military, and has demonstrated a continuing desire to attack the United States, the risk to Americans is great and the President is not bound by law to wait until the final stages of planning or the details of attack to become clear before acting. ${ }^{56}$

These legal justifications by the US government, however, failed to dissuade international condemnation of UAV targeted strikes. Echoing similar arguments from the UN Special Rapporteur, Amnesty International published a report in 2012 accusing the United States

53John Brennan, "Remarks by John Brennan to Harvard Law School-Brookings Institute" (lecture, Harvard Law School, Cambridge, Massachusetts, September 16, 2011).

${ }^{54}$ Eric Holder, “Attorney General Eric Holder Speaks at Northwestern University School of Law” (lecture, Northwestern University, Chicago, IL, March 5, 2012), accessed January 29, 2015, http://www.justice.gov/opa/speech/attorney-general-eric-holder-speaks-northwesternuniversity-school-law.

${ }^{55}$ Ibid.

${ }^{56}$ Ibid. 
of violating basic human rights because UAV targeted killings arbitrarily deprived individuals of life-an inviolate rule that applies even in warfare or times of "public emergency which threatens the life of the nation.”57 The report acknowledged the United States’ inherent right of selfdefense, which allows for lethal force in accordance with international law, and that some of the targeted killings performed in the conflicts within Afghanistan, Pakistan, or Yemen did not violate International Humanitarian Law. Yet the report found that the US policy, as perceived, enables extrajudicial killings anywhere in the world; a violation of IHL based on flawed interpretations of self-defense and imminence, and a reliance on a "global war" legal theory. ${ }^{58}$

The report refuted two legal justifications used by the United States—self-defense and "global war" theory—on grounds that they completely ignore the human rights of targeted individuals. According to Amnesty International, the US justification for targeted killings is one of self-defense in response to the attacks of 9/11 and from a broad reinterpretation of the "imminence" of future terrorist threats. The report acknowledged that Article 51 of the UN Charter does not restrict nations from individually or collectively defending themselves after an attack. However, the report argues the large span of time between the 9/11 attacks and current targeted killings negates Article 51 justification. ${ }^{59}$ Specifically addressing “imminent threats," the report contradicts an accepted belief within international customary law enabling a broader use force in self-defense for anticipatory strikes to prevent imminent attacks. The foundations of the customary law lie within the Caroline case between Great Britain and the United States

${ }^{57}$ Although a single source, the Amnesty International report, 'Targeted Killings' Policies Violate the Right to Life, best summarizes major arguments presented by the international community regarding the inefficacy of targeted killings; Amnesty International, United States of America: 'Targeted Killing' Policies Violate the Right to Life (London: Amnesty International Publications, 2012), 5.

${ }^{58}$ Amnesty International, United States of America, 1-17.

${ }^{59}$ Ibid, 8. 
(1838-1842) ${ }^{60}$ Comparing current targeted killings to the decision from the Caroline case, which held imminence as being "a necessity of self-defence, instant...[with] no moment for deliberation,” demonstrates that targeted killings are not responses to imminent threats. Therefore, UAV targeted killings cannot be justified under either customary law or IHL, revealing the US position of evoking self-defense as untenable and could lead to expansion of situations in which lethal force would be authorized. ${ }^{61}$

Amnesty International further argued the nature of the conflicts against Islamic extremism does not justify the US belief it may use lethal force almost anywhere in the world, against anyone believed to be involved with terrorist organizations, and accept a proportionate number of civilian casualties if in vicinity of the target. ${ }^{62}$ First, deliberate killings contrary to international law are referred to as “extra-legal, arbitrary or summary executions,” or extrajudicial killings and are specifically prohibited under Principle 1 of the UN Principles on the Effective Prevention and Investigation of Extra-Legal, Arbitrary and Summary Executions. Consequently, it is incumbent upon the attacking state to prove that any such killing accorded with international law, which the United States according to Amnesty International, is unable or unwilling to do. Since individuals cannot be targeted for past behavior but upon imminence of the threat they pose, the US broad interpretation of imminence is perceived by some as amounting to

\footnotetext{
${ }^{60}$ The Caroline case involved the seizure and destruction of an American vessel, USS Caroline, by British forces as it was being prepared to support an armed rebellion in the (then) colony of Canada.

${ }^{61}$ Amnesty International, United States of America, 8-9.; American Civil Liberties Union, Amnesty International, Center for Human Rights \& Global Justice (NYU School of Law), et al., “Shared Concerns Regarding U.S. Drone Strikes and Targeted Killings," letter to President Barack Obama, April 11, 2013, accessed January 29, 2015, http://www.hrw.org/sites/default/files/related_material/4-1113_US_LetterToPresidentObamaOnTargetedKillings.pdf.

${ }^{62}$ Amnesty International, United States of America, 4.
} 
extrajudicial killings. ${ }^{63}$ Second, some US methods of conducting UAV targeted strikes-

“signature strikes” and "terrorist attack disruption strikes”-are not discriminatory enough, fail to

protect human life, and may violate international law. ${ }^{64}$ Although the identity of a target is not

required under the laws of war, UAV targeted strikes and signature strikes in particular, increase

the potential risk of targeting civilians. ${ }^{65}$ Finally, the report argues the US policy of considering

all military-age males within the strike-zone as combatants, until post-strike intelligence indicates

otherwise, as a blatant disregard of human rights. ${ }^{66}$ Counterterrorism officials support the "guilty

by association” argument, some of whom have stated anonymously that, "Al Qaeda is an insular, paranoid organization - innocent neighbors don’t hitchhike rides in the back of trucks headed for the border with guns and bombs." ${ }^{67}$ In essence, the United States applies a broad interpretation of “combatant,” which encompasses members of an organized armed group regardless of their participation or activity within military operations - a direct contravention of the laws of war. ${ }^{68}$ Thus, the US prior presumption of guilt enables the killing of unidentified individuals within an area known for terrorist activity, or when they are with known terrorists, and contradicts

${ }^{63}$ Human Rights Watch, Between a Drone and Al-Qaeda: The Civilian Cost of US Targeted Killings in Yemen (New York: Human Rights Watch, 2013), 88.

${ }^{64}$ Amnesty International, United States of America, 5. "Signature strikes" target suspicious buildings or activities even if there is no individual present whose identity is known by the United States. "Terrorist attack disruption strikes" target individuals whose identity is unknown but display activity deemed threatening to the United States. Amnesty International contend both violate International Humanitarian Law.

${ }^{65}$ Human Rights Watch, Between a Drone and Al-Qaeda, 87.

${ }^{66}$ Amnesty International, United States of America, 4.

${ }^{67}$ Jo Becker and Scott Shane, "Secret 'Kill List' Proves a Test of Obama's Principles and Will,” New York Times, May 29, 2012, accessed November 30, 2014, http://www.nytimes.com/2012/05/29/world/obamas-leadership-in-war-on-alqaeda.html?pagewanted=all\&_r=2\&.

${ }^{68}$ Human Rights Watch, Between a Drone and Al-Qaeda, 87. 
statements by the US government and officials, like John Brennan, advocating adherence to international law.

The Amnesty International report highlights specific concerns of the international community regarding the US policy of targeted killings by UAV, while directly refuting two of the primary legal justifications presented by the Obama administration for continuation of the policy. This persistent dialectic demonstrates the contentiousness of the issue and the dilemma of varying interpretations and subsequent application of international laws.

From this analysis of Just War Theory, International Humanitarian Law, and the Law of Armed Conflict it is evident that the United States’ policy on targeted killings by UAVs is a multi-headed animal. From one perspective it is a morally unjust method of warfare in an unjust “war;” from another (US) perspective it is legal application of force in an enduring act of selfdefense against an organized, non-state actor comprised of unlawful combatants; while from yet another (international) perspective it is a gross violation of International Humanitarian Law that uses erroneous interpretations of terms, history, and legalities to support continuing operations. It is no wonder then, that such a policy sets a negative international precedent with almost certain calamitous ramifications for the future. Yet how can the United States determine the long term repercussions of such a contentious practice if replicated by other nations in the future? The following case studies contrast the contemporary policy of targeted killings by UAVs, which invokes domestic and international ire, against similar examples of historically modern weapons systems whose employment also met with increasing criticism or aversion from the international community. The cases reveal suggestions for development of future policy regarding utilization and distribution of new weapons technologies once their employment evolves beyond acceptance by societal norms and establishes a dangerous precedence.

\section{Case Study \#1: Unrestricted Submarine Warfare - Employment Control for a New Technology}

At the beginning of the twentieth century, the relatively new technology of the submarine 
caused a stir in international society. Evolving employment techniques of underwater craft conflicted sharply with military and social norms, i.e. the "collective understandings of the proper behavior of actors,” regarding conventional wisdom of combatant chivalry and propriety of warfare. ${ }^{69}$ Largely believed to fulfill only a defensive function, offensive use of submarines overturned preconceived notions of contemporary conflicts and repulsed many military leaders by usurping their honor-bound ideals of war. Between both World Wars, submarine technology continued to develop as arguments ebbed and flowed between proponents for submarine warfare and advocates arguing its abolishment. The result was a set of internationally accepted rules coordinated over a series of conferences that, although vague and subsequently disregarded during the outbreak of World War II, may serve as a guideline to shape international conduct in war. The distinct revulsion to the submarine is akin to the current issue of targeted killing by UAVs. Like the submarine, the UAV is a relatively new technology initially envisaged in a reconnaissance role, but evolving over the course of two wars into an offensive weapon that continues to evoke trepidation. The development of UAVs, their expanded use on the contemporary battlefield, and consternation throughout the international community regarding conditions of their employment is eerily similar to submarine warfare and enables correlations from which to deduce policy in order to develop an international norm for UAVs in warfare.

Like the UAV, the submarine's potential as a weapon quickly emerged after the invention of a submersible vessel in $1578 .^{70}$ After iterative improvements from various international entrepreneurs, the concept of a submarine evolved into an offensive weapon when Prussia armed an underwater boat in $1772 .{ }^{71}$ From the American Revolutionary War to the early twentieth

\footnotetext{
${ }^{69}$ Jeffrey W. Legro "Which Norms Matter? Revisiting the 'Failure' of Internationalism,” International Organization 51, no. 1 (1997): 33.

${ }^{70}$ Dan Van der Vat, Stealth at Sea (Boston: Weidenfeld \& Nicolson, 1994), 6.

${ }^{71}$ Ibid, 8.
} 
century, the refinement of submarines continued as increases to depth, range, speed, and armament provided greater utility for their employment. Yet the greatest hurdles for proponents of submarines still remained: the blue-water school mentality of contemporary naval powers and the nineteenth century societal bias against "ungentlemanly” warfare. It was these biases that eventually shaped the rules governing submarine warfare throughout the first half of the twentieth century.

By the turn of the twentieth century, Western navies and especially the Royal Navy of Great Britain, perceived the submarine as a dishonorable weapon. As expressed by Admiral Sir Arthur Wilson in 1901 the submarine was “underhand, unfair, and damned un-English,” while the French considered it "underhand, a weapon too terrible to use against an unsuspecting enemy."72 This revulsion to the submarine was due in part to its novelty since submarine warfare, until 1915, was a new concept, and to the cultural norms of the Royal Navy that dogmatically argued the strength of the surface fleet as decisive during sea engagements. ${ }^{73}$ Yet, the potential lethality and power of submarines was not lost on all observers. In 1900, Hugh Oakeley Arnold-Foster, Parliamentary Secretary at the Admiralty, told the House of Commons of Great Britain,

The Admiralty are not prepared to take any steps in regard to submarines because this vessel [sic] is only the weapon of the weaker nation. If, however, this vessel can be rendered practical, the nation which possesses it will cease to be weak, and will become really powerful. More than any other nation, we should have to fear the attacks of submarines. ${ }^{74}$

Consequently, it was cultural views and attitudes that shaped the early twentieth century response to submarine warfare. Technology did not mandate how the submarine would be employed but

${ }^{72}$ Quoted in: Van der Vat, Stealth at Sea, 12 \& 33.

${ }^{73}$ John Terraine, Business in Great Waters: The U-Boat (Barnsely, UK: Leo Cooper Ltd., 1989), 58; Duncan Redford, The Submarine: A Cultural History from the Great War to Nuclear Combat (International Library of War Studies) (Boston: Tauris Academic Studies, 2010), 97.

${ }^{74}$ Quoted in: Van der Vat, Stealth at Sea, 33. 
rather presented choices based on values within each society. ${ }^{75}$ These societal values consequently shaped each country’s negotiations at the multiple conferences convened to discuss rules of warfare, and in many cases the future existence and employment of submarines.

Two conferences prior to World War I addressed submarine and underwater warfare; The Hague Peace Conferences of 1899 and 1907. The first conference extended the Geneva Conventions to war-at-sea but did not outlaw submarine warfare because of a divergence of opinion between the great naval powers. ${ }^{76}$ During both conferences, the cultural and political motivations of each nation were decisive in defining reasons for or against submarine warfare. ${ }^{77}$

Naval warfare dominated the discussion during the second conference with cultural and political aspirations again shaping national arguments. One of the resulting eight naval conventions effectively undercut the intrinsic advantages of the submarine: submarines were required to abide by the same Prize Rules governing surface vessels. ${ }^{78}$ Presumably to the delight of Great Britain, which possessed a robust surface fleet, and frustration of Germany, this exposed frail submarines to the surface fires of armed merchant vessels and negated the submarine's advantage of invisibility and surprise. These constraints inevitably caused Germany to disregard the convention when employing its submarine fleet during World War I.

The constraints and ambiguousness within the 1907 submarine code—specifically the Prize Rules and the inadequate definitions of armed merchant vessels or vessels operating in a military capacity—contributed to Germany’s decision to initiate unrestricted submarine warfare.

${ }^{75}$ Redford, The Submarine, 97.

${ }^{76}$ Van der Vat, Stealth at Sea, 41.

${ }^{77}$ Richard Dean Burns, “Regulating Submarine Warfare,” Military Affairs (1971): 57.

${ }^{78}$ Van der Vat, Stealth at Sea, 42; Burns, “Regulating Submarine Warfare,” 57. The Prize Rule required a submarine reveal itself to stop and search a ship, and warn a vessel while providing safety for its crew prior to destroying it. This became a compromise between abolishing submarines and allowing unrestricted submarine warfare-effectively establishing a submarine code that prevented indiscriminate sinking of merchant ships. 
Britain exploited the nebulous definitions of merchant vessels within the 1907 conventions, believing as Winston Churchill stated,

There are few points on which I am not convinced. Of these is the greatest is the question of the use of submarines to sink merchant vessels. I do not believe this would ever be done by a civilized power... [I do not believe] that the Germans would use submarines for sinking unarmed merchantmen without challenge or any means of rescuing crews. It [is] abhorrent to the immemorial law and practice of the sea. ${ }^{79}$

The power of the Royal Navy combined with the restrictions of the 1907 Conference led Germany to discard the ratified convention and resort to unrestricted submarine warfare in World War I.

To the ire of the American public, unrestricted submarine warfare culminated in the sinking of the RMS Lusitania in 1915 and forced the United States into World War I. News of the sinking was received differently within the United States and Germany, reflecting distinct cultural views regarding the immunity of merchant vessels traversing between belligerents. The sinking divided American opinion. The Des Moines Register and Leader called the destruction of a passenger vessel without regard to passenger safety an act of “deliberate murder," while Vice President Thomas Marshall stated “[when] a person boarded an English vessel he was virtually on English soil and must expect to stand the consequences.”80 Germans supported the sinking, believing the RMS Lusitania was an auxiliary to the Royal Navy and lay fault with the American and British governments for failing to heed German warnings regarding the risk of civilians on board merchant ships. ${ }^{81}$ Despite losing the war, Germany's actions highlighted concerns of the Allies about submarines, and spurred further conferences to determine future constraints of submarine warfare.

${ }^{79}$ Quoted in: Redford, The Submarine, 102.

${ }^{80}$ Charles Tansill, America Goes to War (Boston: Little, Brown and Company, 1942), 276.

${ }^{81} \mathrm{Ibid}, 279$. 
Three major conferences convened during the inter-war period to discuss and limit naval warfare: the Washington Conference (1921), the London Naval Conference (1930), and the London Naval Conference (1936). However, conflicting political and social agendas between nations prevented regulations on submarine warfare-limiting them only by the previously conceived Prize Rules. During the Washington Conference, cultural norms and political agendas again shaped discourse over submarine employment. The resulting treaty of 1922, signed by the United States, France, Great Britain, and Italy essentially required submarines to abide by the Prize Rules or risk liability for acts of piracy. ${ }^{82}$

Divergence of opinion regarding viability of the submarine was even greater during the first London Naval Conference. As a result of changing public opinion and a growing concern over the expansion of submarine fleets within other countries, the United States joined Great Britain in requesting the abolishment of submarine warfare. France staunchly opposed abolishment while Japan and Italy sought to strengthen their navies; Japan wanted submarine parity with the Anglo-Saxon powers and Italy wanted parity with France. The resulting agreement between the naval powers elaborated on the Prize Rules but more importantly, failed to remedy confusion over the role of merchant vessels. The 1930 Treaty stated merchant vessels under the Prize Rules were virtually immune to submarine attacks but did not address the effects of their participation in hostilities or armament on their status of immunity. ${ }^{83}$ As a result, the conference ended with adherence to the status-quo without defining the points of contention regarding merchant vessels that previously led to unrestricted submarine warfare. The second London Naval Conference was even less influential towards submarine warfare than its predecessorsresulting in more than thirty nations agreeing to the abide by the same Prize Rules and

\footnotetext{
${ }^{82}$ Burns, “Regulating Submarine Warfare,” 57.

${ }^{83}$ Ibid.
} 
conventions of the 1921 Washington Conference.

The intent of the conferences was to "humanize” war by developing employment control agreements regarding underwater warfare. However, it became apparent that the code did not conform to the modern concept of war and the binding Prize Rules were so restrictive that they negated the tactical advantage submarines offered. Consequently, at the outbreak of World War II belligerents discarded the Prize Rules—demonstrating the wonton disregard of the code, not a failure of the rules themselves, as the cause for continued unrestricted submarine warfare. ${ }^{84}$

This examination of unrestricted submarine warfare reveals similarities to the issue of targeted killings by UAVs and provides learning points from which to develop strategies for national policy. The cultural aversion to submarine warfare is akin to that regarding UAVs. The Western (especially American) perception of war is a justified action against an evil belligerenttargeting an individual outside the combat zone without warning is contrary to the conspicuously chivalrous backdrop to war. Like the submarine, a UAV is strictly a tool of warfare that does not define its use but provides options for employment within the cultural construct of a society. As noted by the French in 1930, any new technology is at first vilified, but it is the employment based on cultural norms not the technology itself that may be criminal. UAVs are no different; their employment as reconnaissance and offensive platforms were permissible under Western cultural norms until that involved targeting individuals outside a designated combat zone. At that point, UAV employment went outside accepted Western preconceptions of war and their use became questionable.

The conferences that deliberated the use of submarines provide insights that can assist in developing policy for future employment of UAVs. First, there must be a consensus that action is required to limit a technology’s influence in combat. Each nation, whether having or establishing that technology in its military, will have separate cultural norms and political factors requiring

\footnotetext{
${ }^{84}$ Burns, “Regulating Submarine Warfare,” 57.
} 
compromise regarding the technology’s employment. Next, any agreement must be clearly described in detail with each concept defined in order to prevent misconceptions or weakening of the agreement, as was evident in the code of submarine warfare. This will prevent important points from being omitted or overlooked that would lead to abandonment of any future accord at the outset of conflict. Next, routinely scheduled revision and adjustment of the agreement accommodates changes in technology and cultural perceptions in warfare, and prevents relapsing to old rules no longer applicable to the current concepts of warfare. Finally, the agreement must include some measure of enforcement or penalty to ensure adherence during the onset of hostilities. Otherwise, as was the case during both World Wars, belligerents will disregard established rules in pursuit of their military and strategic goals.

\section{Case Study \#2: Nuclear Non-Proliferation - Nonproliferation of New Technologies}

The use of nuclear weapons by the United States against Japan in World War II was the dawn of the nuclear age. Similar to submersible technology earlier in the century, nuclear technology concerned international society to a greater degree due to its capacity to threaten global survival. International concern increased when countries acquired nuclear technology as it evolved to include ever-more destructive weapons. During its four years as the sole nuclear power, the United States made futile attempts to prevent the proliferation of nuclear weapons before the technology and destructive power spread. After the Soviet Union successfully tested its first nuclear weapon in 1949, the immediacy of controlling diffusion of the technology to prevent nuclear conflagration became an international priority. ${ }^{85}$ Between 1945 and 1968, the United States, the Soviet Union, and other nations negotiated to restrict the spread of nuclear weapons believing the technology would destabilize regional balances-of-power and produce global conflict. Although many other non-proliferation régimes emerged during, and subsequently from, 2004): 441.

${ }^{85}$ Paul C. Robinson “Revisiting the Baruch Plan,” Nature 432, no. 7016 (November 25, 
this period, the 1963 Nuclear Test Ban Treaty and the 1968 Nonproliferation Treaty laid the groundwork for international restraint and serve as examples for modern policy. The evolution of the Nonproliferation Treaty contains key factors that are applicable towards drafting a contemporary agreement regarding the proliferation of UAVs due to both technologies' devastating impacts as military weapons, the abhorrence by the international public regarding their employment, and calls for political regulation.

In 1946, US President Harry Truman recognized the enormous threat and destructive power inherent within nuclear weapons and attempted to prevent other nations from realizing nuclear capabilities. Supported by the Acheson-Lilienthal Report (1945), Truman proposed destruction of the US nuclear arsenal and transfer of nuclear weapons research to an international agency. ${ }^{86}$ The goals of the "Baruch Plan" were international control of nuclear research and the eventual elimination of nuclear weapons but it failed to gain traction. ${ }^{87}$ The United States would not destroy its nuclear arsenal until the Soviet Union endorsed the plan and underwent inspections, and the Soviet Union—already in pursuit of a nuclear weapon—rejected the plan immediately. ${ }^{88}$ Without further endorsement for an Atomic Development Authority within the Baruch Plan, the United Nations formed the International Atomic Energy Agency (IAEA) which

\footnotetext{
${ }^{86}$ George Bunn, "The Nuclear Nonproliferation Treaty: History and Current Problems,” Arms Control Association: The Authoritative Source on Arms Control, August 10, 2009, accessed November 15, 2014, http://www.armscontrol.org.; Robinson "Revisiting the Baruch Plan,” 441. Presented by US Representative Bernard Baruch before the first session of the Atomic Energy Commission in 1946, President Eisenhower's plan was the culmination of several international meetings seeking to prevent warfare and future use of nuclear weapons. Within the Baruch Plan, the United States would relinquish its atomic monopoly to a subsequently created United Nations Atomic Development Authority, pending other countries' agreement to cease pursuit of nuclear weapons and submit to inspections. The Atomic Development Authority was intended to be supra-national, invincible to any veto power, and reinforced with military force to conduct inspections, if required.

${ }^{87}$ Robinson “Revisiting the Baruch Plan,” 441. 441.

${ }^{88}$ Bunn, “The Nuclear Nonproliferation Treaty”; Robinson “Revisiting the Baruch Plan,”
} 
possessed limited powers for supervision over nuclear activities. ${ }^{89}$ Aware of the country’s waning nuclear hegemony, the US Congress enacted the Atomic Energy Act of 1946, thereby safeguarding US nuclear technology. ${ }^{90}$ Yet, after the Soviet Union and Great Britain became nuclear powers, more nations sought nuclear capabilities. Nations realized security from a nuclear arsenal — the concept of nuclear deterrence—was the best protection from attack and this became the catalyst for the nuclear arms race. ${ }^{91}$

Upon taking office in 1953, US President Dwight D. Eisenhower revived the need for nuclear non-proliferation while recognizing the benefits of nuclear power. Eisenhower directed the amendment of the Atomic Energy Act of 1946 to authorize transmission of nuclear information to other countries for peaceful purposes. ${ }^{92}$ In the famous "Atoms for Peace” speech (1953), Eisenhower advocated for nuclear-weapons countries to provide non-nuclear-weapons countries the technical knowledge to harness nuclear power for peaceful purposes while agreeing to inspections by the IAEA. ${ }^{93}$ The subsequent dissemination of nuclear expertise and resources assisted with global understanding of nuclear fission and its capabilities, while producing an increased international desire to prevent nuclear proliferation and weaponization. ${ }^{94}$

Despite the benevolent overtones of the Atoms for Peace initiative, atomic weapons continued to evolve in the 1950s. In 1961, following development of the hydrogen bomb and

${ }^{89}$ Robinson "Revisiting the Baruch Plan,” 441.

${ }^{90}$ Bunn, “The Nuclear Nonproliferation Treaty”.

${ }^{91}$ Robinson "Revisiting the Baruch Plan,” 442.

${ }^{92}$ Bunn, "The Nuclear Nonproliferation Treaty”; Robert Cutler to James S. Lay, Jr., memorandum, October 21, 1953, Box 5, no. 18, White House Office of the National Security Council Staff Papers, Executive Secretary Subject Files, Dwight D. Eisenhower Library.

${ }^{93}$ Bunn, “The Nuclear Nonproliferation Treaty”.

${ }^{94}$ Ibid. 
failed nuclear treaties between major powers, the UN General Assembly adopted a nonproliferation resolution introduced by Ireland, which became the first ban on distribution of nuclear material and technology. ${ }^{95}$

Based upon the Irish Resolution, the United States drafted an initial nonproliferation treaty and presented it to the Soviet Union in March 1962 at the Eighteen Nation Disarmament Conference in Geneva. ${ }^{96}$ A few short months later in October, the threat of nuclear war loomed during the Cuban missile crisis, which reemphasized the need to curtail nuclear tests and prevent the proliferation of atomic weapons. After a period of mutual distrust and disagreement over inspection criteria, Soviet and American leaders signed the Limited Test Ban Treaty in August of 1963 - the first nuclear arms control agreement prohibiting nuclear weapons testing in the atmosphere, under water, or outer space. ${ }^{97}$ By 1965, the two nations also achieved a compromise regarding the nonproliferation treaty and empowered the IAEA to conduct inspections to ensure peaceful use of nuclear power, while the United States, Britain, and the Soviet Union pledged to provide assistance to non-nuclear-weapons states, conduct future negotiations to stop the nuclear arms race, and reduce nuclear arsenals with the ultimate objective of nuclear disarmament. ${ }^{98}$ By

\footnotetext{
${ }^{95}$ Lawrence S. Wittner, "Norman Cousins and the Limited Test Ban Treaty of 1963," Arms Control Today 42, no. 10 (December 2012): 1; “The Nuclear Non-Proliferation Treaty (NPT), 1968,” U.S. Department of State: Office of the Historian, accessed October 21, 2014, https://history.state.gov/milestones/1961-1968/npt.; Bunn, “The Nuclear Nonproliferation Treaty”. The ground-breaking “Irish Resolution” became the foundation for the 1968 Nonproliferation Treaty and required states already possessing nuclear weapons not relinquish them, nor provide information regarding nuclear weapons, to states not possessing them.

${ }^{96}$ Bunn, “The Nuclear Nonproliferation Treaty”. During subsequent negotiations, the Soviet Union insisted the United States alter two arrangements with NATO allies-removal of nuclear weapons in West Germany and abandonment of the "multilateral force" concept under which NATO vessels controlled by NATO sailors possessed nuclear weapons. The compromise of 1965 that allowed negotiations to continue required the United States abandon the "multilateral force" concept, while the Soviet Union allow nuclear weapons in West Germany and other countries provided they remained under US control.

${ }^{97}$ Wittner, “Norman Cousins and the Limited Test Ban Treaty of 1963,” 2.

98“The Nuclear Non-Proliferation Treaty (NPT), 1968,” U.S. Department of State: Office of the Historian, accessed October 21, 2014, https://history.state.gov/milestones/1961-1968/npt.;
} 
1968, further negotiations convinced non-nuclear-weapons states to sign the agreement, but by then the previously abstaining French and Chinese had realized their nuclear ambitions alongside the United States, the Soviet Union, and Britain. Thus, the Nonproliferation Treaty was ratified in 1968 by the five nuclear powers and multiple non-nuclear powers, and took full-effect in $1970 .^{99}$

The current manifestation of the Nonproliferation Treaty of 1968 is an enduring, international agreement to prevent further spread of nuclear weapons; to foster peaceful nuclear cooperation under safeguards; and to encourage negotiations to achieve nuclear disarmament. ${ }^{100}$ The lasting effectiveness of the treaty demonstrates the methodology in its development was vital to ensuring its success and should be emulated during construction of future nonproliferation policies. The treaty was based upon the legitimate concerns of a global community that realized the devastating effects of a novel technology if left unchecked, and the disruption to the balanceof-power and accepted norms of warfare if unregulated. Multiple signatories, whether nuclear powers or not, provided legitimacy to the treaty and its long-term goals. The oversight imbedded into the treaty and executed by the international (and unbiased) IAEA provided not only safeguards for adherence but also an element of compliance to the treaty. Periodic reviews ensured the treaty remained relevant as technology developed and non-signatory countries became nuclear powers. Finally, the openness of the treaty allowed current members to promote

\section{Bunn, “The Nuclear Nonproliferation Treaty.”}

99،"The Nuclear Non-Proliferation Treaty (NPT), 1968”; Bunn, “The Nuclear Nonproliferation Treaty.” Under the treaty, all signatories (and those joining in the future) agreed to the following:

1. Not to transfer nuclear weapons or technology to any other state.

2. Non-nuclear signatories agreed not to receive, develop, or acquire nuclear weapons.

3. All agreed to conform to the safeguards established by the IAEA.

4. All agreed to promote and develop peaceful nuclear technologies, and continue negotiations to end the nuclear arms race and limit the spread of nuclear technologies.

5. The treaty's life span was twenty-five years and subject to review every five years (in 1995 it was extended indefinitely).

${ }^{100}$ US Department of State, Fact Sheet: Nuclear Non-Proliferation Treaty, dispatch supplement, 4, no. 3, August 1993. 
peaceful nuclear development, while enabling non-members to join at any time with full rights and responsibilities — both of which added to the credibility and strength of the treaty.

\section{The Dangers of Current Policy and Controls Regarding UAVs}

China is following the precedent set by the U.S. The thinking is that, 'If the U.S. can do it, so can we. They're a big country with security interests and so are we.'

—Siemon Wezeman, Senior Fellow, Stockholm International Peace Research Institute ${ }^{101}$

The United States' successful employment of UAVs in the struggle against Islamic extremism not only shaped strategic thinking and opinion, but caused a global rush to acquire similar capabilities. This UAV arms-race reveals two distinct problems: US policy towards employment and sale of UAVs, and the ineffectiveness of current control regimes designed to prevent proliferation of conventional weapons which include UAVs.

Government reports indicate that between 2005 and 2011, militaries across the globe sought to expand UAV programs and armed-strike capabilities. ${ }^{102}$ Between 2004 and 2011, the number of countries possessing UAVs almost doubled from 41 to $76 .{ }^{103}$ Considered a cheaper weapon or reconnaissance tool, many countries have domestic programs to weaponize their UAVs due to the limited market for purchasing armed variants. ${ }^{104}$ As of 2012 however, the majority of foreign UAVs remained within the tactical rather than strategic category-limited to a 300 kilometer range with an intelligence or reconnaissance purpose. Yet the primarily US

${ }^{101}$ Christopher Bodeen, "China's Drone Program Appears to Be Moving Into Overdrive," World Post, May 3, 2013.

${ }^{102}$ United States Government Accountability Office, Subcommittee on National Security, Homeland Defense, and Foreign Operations, Committee on Oversight and Government Reform, House of Representatives, Nonproliferation: Agencies Could Improve Information Sharing and End-Use Monitoring on Unmanned Aerial Vehicle Exports, GAO-12-536 (Washington, DC: Government Printing Office, 2012), 9.

${ }^{103}$ Ibid.

${ }^{104}$ Wan and Finn, “Global Race On to Match U.S. Drone Capabilities.” 
advantage of strategic UAV capabilities is quickly dissipating. A Teal Group Fairfax report notes that spending on UAV programs is the fastest and most dynamic sector within the global aerospace industry—predicting by 2021 spending will reach $\$ 94$ billion. ${ }^{105}$

China far exceeds any other country in research and development of UAVs, mandating that every major indigenous supplier to the Chinese military devote a section to UAV development. ${ }^{106}$ China seeks not only parity with US capabilities but to capitalize on the burgeoning UAV market by becoming an international supplier. As stated by Zhang Qiaoliang, a representative of Chinese aircraft manufacturer Chengdu Aircraft Design and Research Institute, “The United States doesn’t export many attack drones, so we're taking advantage of that hole in the market...The main reason is the amazing demand in the market for drones after 9/11.” ${ }^{107}$ The Chinese are getting closer to achieving their goal of parity; a 2010 report from the US-China Economic and Security Review Commission stated China "has deployed several types of unmanned aerial vehicles for both reconnaissance and combat,” and possesses several mediumand high-altitude, long-endurance UAVs that provide options for long-range surveillance or attack. ${ }^{108}$ China's advancements in the UAV arms race contribute to regional and global apprehension as well. Within the region, the perceived imbalance of power necessitated Japan and South Korea request the American “Global Hawk” UAV; globally China’s advancements are perceived as erosion of the United States’ pseudo-monopoly on supply of strategic UAVs, which led countries like Pakistan to agreements to purchase armed UAVs from China-its previous supplier of tactical UAVs. ${ }^{109}$

\footnotetext{
${ }^{105}$ Wan and Finn, “Global Race On to Match U.S. Drone Capabilities.”

${ }^{106}$ Ibid.

${ }^{107}$ Ibid.

${ }^{108}$ Ibid.

${ }^{109}$ Ibid.
} 
China is not the only country that concerns the United States. As of 2012, over fifty countries were developing more than 900 different UAV systems with Iran, Russia, India, and Turkey all having strategic UAV programs. ${ }^{110}$ In 2010, Iran unveiled an armed UAV, dubbed the “ambassador of death” by former President Mahmoud Ahmadinejad, but as of 2011 it was not operational. Unconfirmed reports note Russia possesses armed UAVs, while India is developing armed variants with a 30,000 foot ceiling and capable of firing missiles. ${ }^{111}$ In addition to potential adversaries developing UAV capabilities and the threat of unconstrained employment across a battlespace, the arms-race creates a risk of US allies selling UAV technology. Israel sold UAV technology to Germany, France, the United Kingdom, India, and Russia—exporting the "Heron I,” a strategic UAV, on grounds that such sales are vital to the success of its UAV industry. ${ }^{112}$ Although the United States possesses an advantage over foreign UAV threats due to a vast fleet with advanced weapons systems and sensors, along with a robust telecommunications network supporting global deployment, US officials understand that this gap will shrink as foreign capabilities inevitably grow. ${ }^{113}$ Richard Fischer, a senior fellow at the International Assessment and Strategy Center in Washington, summed up succinctly the call for action when addressing the Chinese threat, "[they] are catching up quickly...We should not take comfort in some perceived lags in sensors or satellites capabilities. Those are just a matter of time.”

The international diffusion of UAV capabilities creates an impetus for alteration of current US policy regarding the employment of UAVs on or off the battlefield, as well as their sale on the global market. Since the United States retains the preponderance of UAV capabilities,

${ }^{110}$ United States Government Accountability Office, Nonproliferation, 13.

${ }^{111}$ Wan and Finn, “Global Race On to Match U.S. Drone Capabilities.”

${ }^{112}$ U.S. United States Government Accountability Office, Nonproliferation, 9.

${ }^{113}$ Wan and Finn, “Global Race On to Match U.S. Drone Capabilities.” 
it should shape development of global policy in the dearth of internationally recognized standards constraining UAV employment. ${ }^{114}$ The lack of international employment controls is both a threat to the United States and an opportunity for it, as the leader in UAV technologies, to craft regulations for employment now and in the future. Instead, the United States forges ahead with its current policy bolstered by arguments of national security—undaunted by international opinion because of its monopoly in the field. This is setting dangerous precedence to be imitated by others in the future if not addressed. As noted by Gregg Dubow, UAV targeted killings are proliferating, are too politically convenient, reduce the true costs of war, and can lead to unforeseen repercussions. ${ }^{115}$ For example, although not executed, in 2013 Chinese officials considered using a UAV strike to eliminate a drug lord; demonstrating the intent of nations to imitate the relative sterility and precision of US attacks in combat. ${ }^{116}$ To address UAV employment, the United States should strive to form international agreements on their use, as it did regarding submarine warfare in the inter-war periods, and thereby thwart threats against American interests before they are realized. The United States would lend credence to newly drafted agreements by selfregulating its use of UAVs, thereby reaping the long-term benefits of enhanced national security by proactively circumscribing potential adversaries’ UAV potential.

Amending the United States' policy regarding the sale of UAV technologies to or by other countries would eliminate additional concerns about UAV proliferation. Correctly, the United States views the sale or transfer of American UAV technologies to its allies as strengthening national security. Providing UAV systems to allies aligns each towards a US

${ }^{114}$ Bodeen, “China's Drone Program Appears to Be Moving Into Overdrive.”

${ }^{115}$ Gregg Dubow, “International Watchdog Needed to Monitor Drone Operations,” Atlantic-Community.org - The Open Think Tank on Foreign Policy, October 9, 2013, accessed November 4, 2104, http://www.atlantic-community.org/-/international-watchdog-needed-tomonitor-drone-operations.

${ }^{116}$ Bodeen, “China's Drone Program Appears to Be Moving Into Overdrive.” 
national security objective while simultaneously increasing the ally's ability for independent operations within a region. Additionally, foreign sales defray costs of future development and acquisition, thereby enabling the United States to retain a technological advantage over foreign competitors. ${ }^{117}$ Yet, the United States must do more diplomatically to restrict the sales of UAV technologies by other nations to countries of concern. The rapid ascension of China's UAV industry has created a customer base in many of the regions in which the United States operates militarily. As of 2011, the United States had not pressured China to limit its sales despite its overt intention to become a leading provider of UAV technologies to potential customers in Pakistan, the Middle East, and Africa. ${ }^{118}$ The United States has effectively used diplomacy to register opposition to UAV sales in the past; for example temporarily ejecting Israel from the F-35 Joint Strike Fighter program in objection to Israel’s sale of UAVs to Russia. ${ }^{119}$ However, as demonstrated by Israel, countries will sell UAV technologies based on their national interests unless convinced otherwise, and this requires greater application of US diplomatic leverage to ensure UAV technologies do not fall into the wrong hands.

The growing interest and development in UAV technologies also highlights the inadequacies of the only two, principle multi-lateral export regimes concerning UAVs- the Missile Technology Control Regime (MTCR) and the Wassenaar Arrangement. Both programs are voluntary and attempt to prevent the spread of certain conventional weapons capable of employing weapons-of-mass-destruction (WMDs). The MTCR specifically attempts to limit the proliferation of missiles, rocket systems, UAVs and related technologies capable of carrying 500 kilograms over 300 kilometers or delivery of WMDs. ${ }^{120}$ To achieve these objectives, MTCR

${ }^{117}$ United States Government Accountability Office, Nonproliferation, 20.

${ }^{118}$ Wan and Finn, “Global Race On to Match U.S. Drone Capabilities.” ${ }^{119}$ Ibid.

120“MTCR Missile Technology Control Regime: Objectives,” MTCR Missile Technology Control Regime, accessed November 2, 2014, http://www.mtcr.info/english/objectives.html. 
members adhere to a common export policy containing a common list of controlled items annotated in the Equipment, Software, and Technology Annex (a list of categorized, restricted technologies). However, membership is voluntary and adherence to export guidelines is subject to national legislation and practice of each country. ${ }^{121}$ Consequently, the MTCR remains a “gentlemen’s agreement” and lacks enforcement criteria to ensure compliance. The Wassenaar Arrangement is also a voluntary program, designed to prevent proliferation of certain conventional weapons and sensitive dual-use technologies that have both military and civilian applications. ${ }^{122}$ Participating countries seek to ensure that transfers of arms and dual-use items annotated on mutually agreed upon lists do not contribute to military capabilities that would undermine international or regional stability. ${ }^{123}$ Like the MTCR, countries participating in the Wassenaar Arrangement abide by their national legislation and policies at the full discretion of their government. Neither regime limits the use of listed technologies for civilian or peaceful purposes, but places responsibility upon participating nations to ensure their sales and the employment of the technologies abide by the rules.

Although complimentary to other non-proliferation agreements, the MTCR and Wassenaar Arrangement lack any real impetus for compliance beyond the good intentions of participating nations. This could easily lead nations to abandon or disregard either regime in pursuit of economic gains in light of the UAV arms race. Both appear to have a "club mentality,” meaning they are comprised of the majority of nations that possess the UAV technology in question, which leads to a "haves and have-nots" problem. ${ }^{124}$ This is compounded further

\section{Control Regime.}

121“MTCR Missile Technology Control Regime: Objectives,” MTCR Missile Technology

122“"The Wassenaar Arrangement on Export Controls for Conventional Arms and DualUse Goods and Technologies,” The Wassenaar Arrangement, November 4, 2014, accessed November 4, 2014, http://www.wassenaar.org/publicdocuments/index.html.

${ }^{123}$ Ibid.

${ }^{124} \mathrm{C}$. Michael Cali, “UAV Proliferation and the Challenge of Change,” Georgetown 
because many UAV technologies listed have a dual-use capability yet are restricted because of their applicability towards military utilization.

Consequently, the current control regimes do not adequately address the growth of the international UAV industry or the inherent threats of the technology as it expands into national militaries. Both the MTCR and Wassenaar Arrangement regulate the distribution of UAV technology to some degree but fail in promoting genuine non-proliferation because they are voluntary, self-regulating, and lack coercive compliance measures. Neither regime addresses the employment of UAVs in specific detail, revealing the dearth of any international agreement or consensus regarding use of UAVs in general. As the leader in UAV capabilities, the United States, instead of continuing on its current path, must spearhead an effort to shape international policy regarding not only the proliferation of UAV technology but also its employment. In doing so, the United States can promote international security by strengthening current control measures and filling the gap regarding UAV proliferation measures.

\section{Conclusion}

As noted, UAV targeted killings are quickly becoming the "only game in town” when confronting terrorist organizations on non-contiguous battlefields or outside designated combat areas because of a perception that their accuracy can limit collateral damage. Viewed through either a lens of Just War Theory or IHL/LOAC, executing UAV targeted killings is a contentious issue with advocates and opponents claiming legitimacy of their arguments. Yet the argument is not that simple because problems of morality compound the problems of legality. Even if current US policy is justified legally, as actions under an Article 3 conflict, international perception of the United States breaking international law by violating a country’s sovereignty and individuals’ rights dominates the narrative. Although erroneous from a US perspective, this perception risks becoming reality and purports the criminality of the United States pursuing military objectives

Journal of International Affairs (October 9, 2013), accessed November 4, 2014, http://journal.georgetown.edu/uav-proliferation-and-the-challenge-of-change-by-c-michael-cali/. 
despite violations of the law. Consequently, the danger is establishing a new international norm allowing states to disregard or interpret international law to suit political ends.

UAV capabilities are rapidly evolving in numerous countries that wish to replicate US successes in Iraq, Afghanistan, and elsewhere. The absence of international consensus or regulation regarding UAV employment, combined with weak nonproliferation regimes, exacerbates future dangers if the United States continues to legitimize its use of UAVs without regard for international opinion or subsequent threat of emulation. This fuels the negative perception of US actions as criminal and bolsters establishment of a dangerous, new norm. Whether or not they are of concern to the United States, other nations, especially China, are attempting to achieve UAV parity and exploit the market for UAV technology sales noting that "if the US can do it, then so can we."

As demonstrated by the case studies, regulation of a weapons system can occur in a variety of ways. Much like the nuclear arms race, international parity with the United States regarding UAV technologies could result in nullifying a US advantage and ability to conduct targeted killings due to the threat, and balancing effect of possible reciprocation. Also, similar to the Prize Rules applied against submarine warfare, application of a contemporary customary law governing manned aircraft strikes could regulate UAV targeted killings. As inferred from a sampling of manned-aircraft strikes outside designated conflicts within the past three decades, nations adhere to customary law that generally regulates when and under what conditions manned-aircraft strikes may occur. ${ }^{125}$ Finally, much like the attempts at regulating submarine

${ }^{125} \mathrm{~A}$ customary law can be inferred from the manned aircraft-strikes within Libya (1986) under Operation El Dorado, Kosovo (1999) under Operation Allied Force, and Libya (2011) under Operation Unified Protector; all of which conformed to similar rules before and during execution. In all three cases, airstrikes were a response to aggression and targeted military or government entities. Each operation was predicated on legitimacy through either international support, or resolutions from the United Nations or North Atlantic Treaty Organization. Finally, each operation forewarned the targeted nations prior to attack. For more information regarding Operation El Dorado, see: Henry W. Prunckun, Jr. and Philip B. Mohr, "Military Deterrence of International Terrorism: An Evaluation of Operation El Dorado Canyon," Studies in Conflict and Terrorism 20, no. 3 (July 15, 1996): 267-80, accessed February 18, 2015, 
warfare through the creation of international protocol, a similar set of standards regulating UAV employment could greatly reduce the dangers and public blowback associated with targeted killings. Although establishment of a new regulation regime isn’t required, since waiting for parity or applying a similar customary law to UAVs would achieve similar employment controls, action must be taken in some form to constrain UAV use and prevent duplication of a dangerous precedent.

The effectiveness of UAVs opened a Pandora's Box the United States must not ignore: establishment of international precedence that targeted killings of individuals may occur whenever a nation evokes the right of self-defense regardless of the location, conditions of conflict, immediacy of the threat, or status of the individual. UAVs are the contemporary vehicle by which this dilemma has materialized, yet the ramifications of current US policy—future imitation and legitimation-are more severe. If the United States does not lead development of an international agreement that regulates the use and sale of UAVs, by first aborting its current practices, than this US policy will be used to justify similar actions by other countries in the future regardless of the weapons technology employed. In other words, in the future nations could claim US precedence justifies a first-strike attack on an enemy outside a designated combat zone, using either contemporary or future weapons technologies, when evoking self-defense because the threat of imminent attack is omnipresent. These second and third-order effects to the policy of UAV targeted killings should act as the impetus for international regulation of UAV technologies.

http://www.tandfonline.com/doi/pdf/10.1080/10576109708436039; or, Kennedy Hickman, "International Terrorism: Bombing of Libya (Operation El Dorado Canyon)," About Education, 2015, accessed February 18, 2015, http://militaryhistory.about.com/od/aerialcampaigns/p/ColdWar-1986-Bombing-Of-Libya-Operation-El-Dorado-Canyon.htm; for Operation Allied Force, see: Daniel L. Byman and Matthew C. Waxman, "Kosovo and the Great Air Power Debate," International Security 24, no. 4 (Spring 2000): 5-38, accessed February 18, 2015, http://www.jstor.org/stable/2539314; for Operation Unified Protector, see: Geir Ulfstein and Hege Fosund Christiansen, "The Legality of the NATO Bombing in Libya," International and Comparative Law Quarterly 62, no. 1 (January 2013): 161, accessed February 18, 2015, http://journals.cambridge.org/abstract_S0020589312000565. 
Leading the development of binding international agreements by first circumscribing its own UAV employment methods, the United States can shape international opinion and policy regarding not only the use of UAVs but the parameters for targeting individuals in future conflicts.

\section{Recommendations}

The proliferation of UAV technology internationally and the corresponding trend favoring targeted killings via UAVs necessitate greater employment control and nonproliferation regimes. As in the past, employment control and nonproliferation policies augment the US national security strategy — especially in view of the long-term ramifications of current US practices. ${ }^{126}$ The United States, preeminent in the field of UAVs, has a positional advantage and should spearhead international efforts to regulate UAV employment as well as distribution of UAV technology. The timing for regulation is now; support for international restraint is more likely when new weapons technology is less dispersed and leading nations self-regulate as part of a wider effort to mitigate others' perceived threats of vulnerability. ${ }^{127}$ The resulting self-imposed restraint of the United States through the multilateral negotiations process will provide legitimacy to any forthcoming treaty and encourage additional signatories' adherence in the future. As the advocate for change, the United States can appease both domestic and international consternation regarding its use of UAVs in combat while ensuring that such actions are not reciprocated in kind nor imitated on a larger scale in the future from a precedent set today.

${ }^{126}$ US Library of Congress, CRS, Arms Control and Nonproliferation: A Catalog of Treaties and Agreements, by Amy F. Woolf, Paul K. Kerr, and Mary Beth D. Nikitin, CRS Report RL33865 (Washington, DC: Office of Congressional Information and Publishing, July 21, 2014), 1.

${ }^{127}$ The aforementioned international support for the 1968 Nonproliferation Treaty justifies this proposition. With the exception of China and France, both of which ratified the treaty only after achieving nuclear-weapons capabilities, most non-nuclear weapons countries supported the efforts of the nuclear powers to regulate the use and proliferation of nuclear technology due to their vulnerability. See "The Nuclear Non-Proliferation Treaty (NPT), 1968." 
Analysis of unrestricted submarine warfare and post-World War II non-proliferation shows that success of any future UAV treaty relies upon compliance to the agreement based upon legitimacy and enforcement. Compliance results from normative legitimacy of the rule, i.e. the rule is perceived as legitimate in itself or from the institution that established the rule. ${ }^{128}$ The preponderant international aversion to targeted killings by UAVs supports limiting the practice and constitutes normative legitimacy. By empowering an international organization, like the United Nations, to develop, oversee, and enforce compliance to the treaty, the United States provides additional legitimacy through the institution. Enforcement of the treaty requires "smart power” as defined by Joseph S. Nye; the combination of both hard and soft power into effective strategies. ${ }^{129}$ Legitimacy and acceptance of the treaty ensure initial compliance, but coercion through punitive actions for violations or incentives for adherence are the hard power that enforces the treaty.

Consequently, the United States should spearhead efforts within the United Nations for development of a "UAV Employment Control \& Nonproliferation Treaty” modeled after the UN Arms Trade Treaty of 2013 and the Convention on Certain Conventional Weapons of 1983 (CCW), with oversight from a newly created UN agency specifically charged with implementation and enforcement. Although voluntary, all signatories to the treaty would agree to abide by the rules established within the treaty as well as mandates from the governing UN agency.

The UAV Employment Control \& Nonproliferation Treaty would include regulations regarding the distribution of UAV technology and use of UAVs in subsequent conflicts. It would

${ }^{128}$ Ian Hurd, "Legitimacy and Authority in International Politics," International Organization 53, no. 2 (Spring 1999): 379-408, accessed November 3, 2014, http://www.jstor.org/stable/2601393.

${ }^{129}$ Joseph S. Nye, The Future of Power (New York: Public Affairs, 2011), 1-24. 
be based on four fundamental concepts: every state has the right to develop UAVs for civilian and military purposes; during times of peace, a state may not operate UAVs within another state without consent; states possessing UAVs must not provide UAV technology to terrorist or radicalized organizations; and states possessing armed UAVs must abide by the Geneva Conventions when using them in a conflict. ${ }^{130}$ Like the UN Arms Trade Treaty, the new accord would aim to prevent the illicit trade in UAV technology while recognizing states' legitimate economic, political, security, and commercial interests regarding UAVs. ${ }^{131}$ It would list and specifically define the UAV components, parts, and supporting technologies controlled under the treaty while requiring signatories submit periodic reports for implementation and compliance with the treaty. Similar to the CCW, the UAV treaty would endorse international law: states’ methods or means of warfare are not unlimited; civilians and non-combatants shall remain protected during conflict; and state sovereignty is inviolate. ${ }^{132}$ Like the CCW, the UAV treaty must address in its scope of application Article 2 and 3 conflicts and those not of international character but occurring within the territory of other countries, in order to prevent the dangerous second and third-order effects resulting from imitation of current practices. Finally, even during conflicts involving parties on disparate sides of the UAV Treaty, signatories would be required to conform to the limitations prescribed within the treaty.

Unlike either the UN Arms Trade Treaty or the CCW, which allow self-enforcement, compliance to the UAV treaty would require the oversight of a UN organization. This agency would utilize a “stick and carrot method,” by providing rewards for inclusion under and

${ }^{130}$ Dubow, “International Watchdog Needed to Monitor Drone Operations.”

${ }^{131}$ United Nations Arms Trade Treaty, Multilateral, April 2, 2013, UNTS Pending, 1.

${ }^{132}$ United Nations Convention on Prohibitions or Restrictions on the Use of Certain Conventional Weapons which may be deemed to be Excessively Injurious or to have Indiscriminate Effects, Multilateral, December 2, 1983, UNTS 1342, 1-2. 
compliance with the treaty, and punishments for violations. Good-standing members of the treaty would enjoy transparency between states regarding UAV operations as well as freedom to buy, sell, or transfer UAV technology between member states. Violations of the treaty would result in export controls, limited access to UAV expertise, and economic sanctions against the offending state, as enforced by the UN agency and supported by member states. ${ }^{133}$ Adhering to the treaty's regulations during conflict would be the most difficult to impose without sacrificing national or military security for the sake of transparency. ${ }^{134}$ Consequently, this would be the only "selfregulating” aspect of the treaty and reliant upon nations' commitment to the treaty. Historical evidence proves that when nations view a treaty as legitimate, as is often the case with chemical and biological weapons, they readily adhere to the treaty knowing other states will too. By promoting something akin to the UAV Employment Control \& Nonproliferation Treaty, the United States will enhance its national security by shaping how and to whom UAV technology is provided, by regulating the environment within which and how UAVs are employed today as well as in the future, and by dictating precedence set today that won't evolve to egregious proportions in the future.

${ }^{133}$ Randall Forsberg et al., Non-Proliferation Primer: Preventing the Spread of Nuclear, Chemical, and Biological Weapons (Cambridge: MIT Press, 1995), 73-95.

${ }^{134}$ Ibid. 


\section{Bibliography}

Amnesty International. United States of America: 'Targeted Killing' Policies Violate the Right to Life. London: Amnesty International Publications, 2012.Aquinas, Thomas (Saint). The Summa Theologica, ed. and trans.by the Fathers of the English Dominican Province (Benziger Brothers Edition, 1947), accessed on September 21, 2014, http://dhspriory.org/thomas/summa/.

Benson, Pam. "U.S. Airstrikes in Pakistan Called 'Very Effective'.” CNNPolitics.com. Last modified May 8, 2009. Accessed September 23, 2014. http://www.cnn.com/2009/POLITICS/05/18/cia.pakistan.airstrikes/.

Bergen, Peter, and Katherine Tiedmann. "Washington's Phantom War: The Effects of the U.S. Drone Program in Pakistan.” Foreign Affairs 90, no. 4 (2011), accessed March 8, 2015, http://www.foreignaffairs.com/articles/67939/peter-bergen-and-katherinetiedemann/washingtons-phantom-war.

Brennan, John. "Remarks by John Brennan to Harvard Law School-Brookings Institute.” Lecture, Harvard Law School, Cambridge, Massachusetts, September 16, 2011.

Bunn, George. “The Nuclear Nonproliferation Treaty: History and Current Problems.” Arms Control Association: The Authoritative Source on Arms Control. August 10, 2009. Accessed November 15, 2014. http://www.armscontrol.org.

Burns, Richard Dean. “Regulating Submarine Warfare.” Military Affairs (1971): 57.

Byman, Daniel. “Do Targeted Killings Work?” Foreign Affairs 85, no. 2 (2006), accessed March 8, 2015, http://www.foreignaffairs.com/articles/61513/daniel-byman/do-targeted-killingswork.

Byman, Daniel L., and Matthew C. Waxman. "Kosovo and the Great Air Power Debate.” International Security 24, no. 4 (Spring 2000): 5-38. Accessed February 18, 2015. http://www.jstor.org/stable/2539314.

Cali, C. Michael "UAV Proliferation and the Challenge of Change.” Georgetown Journal of International Affairs (October 9, 2013). Accessed November 4, 2014. http://journal.georgetown.edu/uav-proliferation-and-the-challenge-of-change-by-cmichael-cali/.

Christopher, Paul. The Ethics of War and Peace: An Introduction to Legal and Moral Issues. 3rd ed. New Jersey: Person/Prentice Hall, 2004.

Cicero, Marcus Tullius. "Book III.” In De Re Publica [Concerning the 'Republic' or 'Commonwealth']. Translated by Francis Barham, under "Fragments,” Mohrsville, PA: Kings Academy, 2011. Accessed January 22, 2015. http://www.kingsacademy.com/mhodges/08_Classics-Library/hellenist-roman/cicero/dere-publica/de-re-publica.htm.

De Laurentis, Jeffrey. Civil and Political Rights, Including the Questions of: Disappearances and Summary Executions. United Nations Economic and Social Council, Commission on Human Rights, 59 ${ }^{\text {th }}$ sess., Agenda item 11(b). Geneva, Switzerland, 2003. 
Drones Team. "Yemen: Reported Us Covert Actions 2001-2011.” The Bureau of Investigative Journalism. March 29, 2012. Accessed November 29, 2014.

http://www.thebureauinvestigates.com/2012/03/29/yemen-reported-us-covert-actionssince-2001/.

Dubow, Gregg. “International Watchdog Needed to Monitor Drone Operations.” AtlanticCommunity.org - The Open Think Tank on Foreign Policy. October 9, 2013. Accessed November 4, 2014. http://www.atlantic-community.org/-/international-watchdog-neededto-monitor-drone-operations.

Forsberg, Randall, William Driscoll, Gregory Webb, and Jonathan Dean. Non-Proliferation Primer: Preventing the Spread of Nuclear, Chemical, and Biological Weapons.

Cambridge: MIT Press, 1995.

Grotius, Hugo. The Law of War and Peace (1625). Translated by Francis Kelsey, New York: Bobbs-Merrill, 1962. Accessed January 17, 2015.

http://lonang.com/library/reference/grotius-law-war-and-peace/gro-201/

Hickman, Kennedy "International Terrorism: Bombing of Libya (Operation El Dorado Canyon)." About Education. 2015. Accessed February 18, 2015.

http://militaryhistory.about.com/od/aerialcampaigns/p/Cold-War-1986-Bombing-Of-LibyaOperation-El-Dorado-Canyon.htm.

Holder, Eric. “Attorney General Eric Holder Speaks at Northwestern University School of Law.” Lecture, Northwestern University, Chicago, IL, March 5, 2012. Accessed January 29, 2015. http://www.justice.gov/opa/speech/attorney-general-eric-holder-speaks-northwesternuniversity-school-law.

Human Rights Watch. Between a Drone and Al-Qaeda: The Civilian Cost of US Targeted Killings in Yemen. New York: Human Rights Watch, 2013.Hurd, Ian. "Legitimacy and Authority in International Politics.” International Organization 53, no. 2 (Spring 1999): 379-408. Accessed November 3, 2014. http://www.jstor.org/stable/2601393.

International Committee of the Red Cross: Customary International Humanitarian Law (IHL). “Customary International Humanitarian Law (IHL): Rules by Chapter.” Under Rules 3, 5, \& 6. 2015. Accessed January 30, 2015. https://www.icrc.org/customaryihl/eng/docs/v1_cha.

International Committee of the Red Cross (ICRC): Customary International Humanitarian Law (IHL). "Rule 70. Weapons of a Nature to Cause Superfluous Injury or Unnecessary Suffering.” Accessed January 22, 2015. https://www.icrc.org/customaryihl/eng/docs/v1_cha_chapter20_rule70\#Fn_66_23.

International Committee of the Red Cross (ICRC). International Humanitarian Law and the Challenges of Contemporary Armed Conflicts. Geneva, Switzerland: 30 ${ }^{\text {th }}$ International Conference of the Red Cross and Red Crescent, 2007.

International Committee of the Red Cross (ICRC): Treaties and States Parties to Such Treaties. "Convention (III) Relative to the Treatment of Prisoners of War. Geneva, 12 August 1949.” Accessed January 17, 2015. https://www.icrc.org/ihl/WebART/375-590006. 
International Committee of the Red Cross (ICRC): Treaties and States Parties to Such Treaties. "Protocol Additional to the Geneva Convention of 12 August 1949, and Relating to the Protection of Victims of International Armed Conflicts (Protocol I), 8 June 1977." Accessed January 17, 2015. https://www.icrc.org/ihl/4e473c7bc8854f2ec12563f60039c738/8a9e7e14c63c7f30c12563 cd0051dc5c?OpenDocument.

International Review of the Red Cross. Interpretive Guidance on the Notion of Direct Participation in Hostilities under International Humanitarian Law. Geneva: International Committee of the Red Cross, 2009.

Kier, Elizabeth, and Jonathan Mercer. "Setting Precedents in Anarchy: Military Intervention and Weapons of Mass Destruction.” International Security 20, no. 4 (Spring 1996): 77-106. Accessed November 26, 2014. http://www.jstor.org/stable/2539043.

Koh, Harold Hongju. “The Obama Administration and International Law.” Lecture, Annual Meeting of the American Society of International Law, Washington, DC, March 25, 2010. Accessed September 4, 2014. http://www.state.gov/s/l/releases/remarks/139119.htm.

Legro, Jeffrey W. “Which Norms Matter? Revisiting the 'failure' of Internationalism.” International Organization 51, no. 1 (1997).

MTCR Missile Technology Control Regime. "MTCR Missile Technology Control Regime: Objectives.” Accessed November 2, 2014. http://www.mtcr.info/english/objectives.html.

Nye, Joseph S. The Future of Power. New York: Public Affairs, 2011.

O'Connell, Mary Ellen. International Law and the Use of Force. New York: Foundation Press, 2005.

Patterson, Eric. Just War Thinking: Morality and Pragmatism in the Struggle Against Contemporary Threats. Plymouth: Lexington Books, 2007.

Peters, Ralph. “A Revolution in Military Ethics?” Parameters (Summer 1996): 102-8. Accessed December 18, 2014. http://strategicstudiesinstitute.army.mil/pubs/parameters/Articles/96summer/peters.htm.

Prunckun, Jr., Henry W., and Philip B. Mohr. "Military Deterrence of International Terrorism: An Evaluation of Operation El Dorado Canyon.” Studies in Conflict and Terrorism 20, no. 3 (July 15, 1996): 267-80. Accessed February 18, 2015. http://www.tandfonline.com/doi/pdf/10.1080/10576109708436039.

Redford, Duncan. The Submarine: A Cultural History from the Great War to Nuclear Combat (International Library of War Studies). Boston: Tauris Academic Studies, 2010.

Robinson, Paul C. “Revisiting the Baruch Plan.” Nature 432, no. 7016 (November 25, 2004).

Roggio, Bill. “Charting the Data for Us Airstrikes in Pakistan, 2004-2014.” The Long War Journal. Last modified November 11, 2014. Accessed September 23, 2014. 
http://www.longwarjournal.org/pakistan-strikes.php.

Solis, Gary D. The Law of Armed Conflict: International Humanitarian Law in War. New York: Cambridge University Press, 2010.

Tansill, Charles America Goes to War. Boston: Little, Brown and Company, 1942.

Terraine, John. Business in Great Waters: The U-Boat. Barnsely, UK: Leo Cooper Ltd., 1989.

The Wassenaar Arrangement. "The Wassenaar Arrangement on Export Controls for Conventional Arms and Dual-Use Good and Technologies.” Accessed November 4, 2014. http://www.wassenaar.org/publicdocuments/index.html.

Tunis, Edwin. Weapons: A Pictorial History. Baltimore: Johns Hopkins University Press, 1999.

Ulfstein, Geir, and Hege Fosund Christiansen. "The Legality of the NATO Bombing in Libya." International and Comparative Law Quarterly 62, no. 1 (January 2013): 161. Accessed February 18, 2015. http://journals.cambridge.org/abstract_S0020589312000565.

US Department of State: Office of the Historian. "The Nuclear Non-Proliferation Treaty (NPT), 1968.” Accessed October 21, 2014. https://history.state.gov/milestones/1961-1968/npt.

US Department of State. Fact Sheet: Nuclear Non-Proliferation Treaty. Dispatch supplement 4, no. 3, August 1993.

US Government Accountability Office. Nonproliferation: Agencies Could Improve Information Sharing and End-Use Monitoring on Unmanned Aerial Vehicle Exports, by Thomas Melito, July 2012.

US Library of Congress. Congressional Research Service. Arms Control and Nonproliferation: A Catalog of Treaties and Agreements, by Amy F. Woolf, Paul K. Kerr, and Mary Beth D. Nikitin, CRS Report RL33865. Washington, DC: Office of Congressional Information and Publishing, July 21, 2014.

United Nations. Arms Trade Treaty, Multilateral. April 2, 2013. UN Treaty Series pending.

United Nations. Convention on Prohibitions or Restrictions on the Use of Certain Conventional Weapons which may be deemed to be Excessively Injurious or to have Indiscriminate Effects, Multilateral. December 2, 1983. UN Treaty Series 1342.

US, Department of the Army. Army Doctrine Publication (ADP) 1-0, The Army Profession. Washington, DC: Government Printing Office, 2013.

Van der Vat, Dan Stealth at Sea. Boston: Weidenfeld \& Nicolson, 1994.

Victoria, Franciscus de. De Indis et de Ivre Belli Relectiones (Being Parts Of) Relectiones Theologicae XII. In The Classics of International Law. Edited by James Brown Scott and Ernest Nys. Translated by John Pawley Bate. Washington: Carnegie Institution of Washington, 1917. Accessed January 17, 2015. http://babel.hathitrust.org/cgi/pt?id=mdp.39015039506772;view=1up;seq=11. 
Williams, Brian Glyn. “The CIA’s Covert Predator Drone War in Pakistan, 2004-2010: The History of an Assassination Campaign.” Studies in Conflict and Terrorism 33 (2010): 871.

Wittner, Lawrence S. “Norman Cousins and the Limited Test Ban Treaty of 1963.” Arms Control Today 42, no. 1 (December 2012). 